\title{
高層建物の帳壁緊結部疲労損傷評価用風外力の検討 CHARACTERISTICS OF WIND FORCES ACTING ON EXTERNAL WALL BINDERS OF HIGH-RISE BUILDINGS FROM THE VIEWPOINT OF FATIGUE DAMAGE
}

\author{
寺 崎 浩*, 植 松 康**
}

Hiroshi TERAZAKI and Yasushi UEMATSU

\begin{abstract}
The present paper discusses the characteristics of wind forces acting on the external wall binders of a high-rise building based on the results of a wind tunnel experiment from the viewpoint of fatigue damage. Special attention is paid to the binders connecting the external curtain walls and the structural frames. A wind force direction conversion factor for the relation between wind force and member stress is introduced into the fatigue evaluation together with the normalization of stresses. Furthermore, a discussion is also made of the influence of mean stress on the fatigue damage, which depends on the wind direction and speed.
\end{abstract}

Keywords : Fatigue damage, External wall, High-rise building, Cladding and components, Wind tunnel experiment, External wall binder 疲労損傷, 帳壁, 高層建物, 外装材, 風洞実験, 帳壁緊結部

1. はじめに

高層建物の外装材は日常的な弱風から台風などの強風まで, 常に 風外力にさらされている。風外力は地震外力に比べて継続時間が極 端に長いという特徵を有するため, 外装材は風外力による疲労損傷 を受けやすいと考えられる。高層建物の構造骨組部材は，再現期間 500 年の風荷重（以下,L2）に対して概ね弾性となるように設計され ているが，外装材は再現期間 50 年の風荷重（以下,L1）に対して短 期許容応力度で設計されるのが一般的である。したがって, 建物の 供用期間中に疲労損傷する可能性も考えられ, 疲労損傷の適切な評 価や防止は設計上重要である。

建築物の外装材の疲労に関する研究は，海外では主に低層建物の 屋根に着目した検討がなされており 1)-3)，国内でも中低層建物屋根

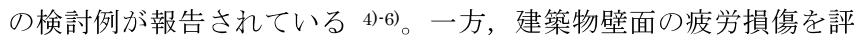
価している研究はあまり多くなく, 既往の研究では接近流の特性に 基づいて応力振幅回数を約 1 回／sec と仮定した検討がなされてい る7),8)。さらに高層建物の壁面を対象とした研究は少なく9)，その中 でも風向の変化を考慮した検討はほとんどない。そこで，本論文で は, 高層建物の帳壁緊結部を構成する部材の中で応力的に最も厳し い状態と考えられるボルトを検討対象部位とし, 風向分布や風外力 の平均成分も考慮した検討を実施することとした。

外装材の疲労評価の最終目標は，仮定した建物について建物供用 期間中（数十年〜数百年程度）の建設サイトにおける風向および風 速の発生頻度分布（台風等の強風も含む）を仮定し, 建物の配置 (方 位）も考慮して, 疲労による破壊が発生するか否か, 疲労破壊に至
らないまでも部材に蓄積される疲労損傷率がどの程度の值となるの かを検討・判断することである。本論文では，上記の疲労評価の流 れの中から, 前半部分の風向・風速に応じて評価部位に蓄積する 10 分間疲労損傷率の評価とその評価に用いる外力特性の検討までを対 象範囲とし，以下の 2 点を目的とした検討を行った。

・作用する風外力として塔状比 4 の基本角柱の変動風圧実験結果を 用い，疲労損傷率の壁面上の分布状況に基づいて相対的に大きな疲 労損傷率が発生する代表部位を選定し, 疲労傷率算定に用いる評価 用風外力の特性（風向, 風速, 応力振幅の振幅分布や発生回数, 平 均成分の存在）とそれらが損傷率に与える影響を詳細に検討する。

・上記の検討に基づいて, 風向・風速に対応した疲労損傷率を比較 的簡便に評価する近似式と算定に必要な変数の值を提案する。近似 式は将来の一般化に向けて, 実験の風圧統計值に基づく汎用的な形 で示すが，現状の適用範囲は論文中の実験に対応したケースについ て論文中の実験結果および変数值に基づいて算定する場合のみとす る。

\section{2. 検討概要}

\section{1 設計風速 $U_{\mathrm{HD}}$ と疲労検討風速 $U_{\mathrm{H}}$ について}

本論文では, 検討対象建物の外装材耐風設計(耐力設計)に用いる 再現期間 50 年の $\mathrm{L} 1$ レベルの風速を $U_{\mathrm{HD}}$ とする。 $U_{\mathrm{HD}}$ は検討建物の 建設地を東京, 地表面粗度区分をIII と仮定して，平成 12 年建設省 告示 1454 号に与えられる風速 $V_{0}=34 \mathrm{~m} / \mathrm{s}$ に基づいて建物代表高さ $H$ で算定する。一方，疲労損傷の検討では，建物供用期間中に受ける

\footnotetext{
本論文は日本建築学会大会学術講演会(東海，2012.09，北海道，2013.08）および日本風工学シンポジウム(東京，2012.12)に拈いて発表した内容に，修正・追加検討を加え，さ らに発展させたものである。 
風速範囲について疲労損傷率を算定する必要があるため, 疲労損傷 率の算定式では建物代表高さ $H$ における風速を $U_{\mathrm{H}}$ と記載する。

\section{2 検討建物・検討部位の概要}

検討対象として高さ $H=200 \mathrm{~m}$, 幅 $B=50 \mathrm{~m}$, 奥行 $D=50 \mathrm{~m}$, 塔状比 4 の超高層建物を想定した。外装材の帳壁には代表寸法が幅 $1.8 \mathrm{~m} \times$ 高さ $4.8 \mathrm{~m}$ のカーテンウオール（以下， C.W.）を仮定した。C.W.の 耐風設計では, 設計荷重に対して C.W. 主要部材のたわみ制限がある ため C.W. 本体は比較的剛な構造となっている。そのため, C.W.本 体の部材と応力伝達径路部材の中では緊結部のボルトが応力的に最 も厳しい部位となると考えられる。

一般の耐風設計では C.W.のような外装材本体は剛と仮定して部 材の共振効果は無視して外装材に作用するピーク風力に対して部材 を設計していることから, 本検討においても C.W.本体の共振効果は 無視して C.W.に直接作用寸る風力時刻歷から疲労検討用応力度の 時刻歴を算定することとした（以下，本論文中では単位面積あたり の応力である応力度についても応力と記述する)。

本論文で対象とする C.W.では, Fig. 1 に示すようなファスナー部 の納まりで C.W.を建物外部方向に引っ張る負の風力が作用し緊結 部ボルトに引張力が発生する場合を主に想定する。

検討部位のボルトは強度区分 4.6 の鋼製ボルト（降伏応力 $\left.\sigma_{\mathrm{y}}=240 \mathrm{~N} / \mathrm{mm}^{2}\right)$ を仮定し, ボルトの総断面積 $a$ は, 再現期間 50 年 の外装材設計用風速 $U_{\mathrm{HD}}$ のとき帳壁端部ピーク風力係数 $\hat{C}_{\mathrm{fD}}$ （室内 圧 $=0$ と仮定）に対応寸る設計応力 $\sigma_{\mathrm{D}}$ が， $\sigma_{\mathrm{D}}=0.5 \sigma_{\mathrm{y}}, \sigma_{\mathrm{D}}=0.8 \sigma_{\mathrm{y}}$, $\sigma \mathrm{D}=1.0 \sigma_{\mathrm{y}}$ の 3 種類となるように設定する。なお, 本検討では簡単お よび比較のため全ての帳壁が同一の仕様で設計・施工されていると 仮定する。

以上より, 外装材緊結部一箇所あたりの設計用ピーク風力 $P_{\mathrm{D}}$ と それに対応した設計用ピーク応力のは, 以下の式で与えられる。

$$
\begin{aligned}
& P_{\mathrm{D}}=\left|\hat{C}_{\mathrm{f}_{\mathrm{D}}}\right| q_{\mathrm{HD}} A \quad(\mathrm{~N}) \\
& \sigma_{\mathrm{D}}=\frac{P_{\mathrm{D}}}{a}=\left|\hat{C}_{\mathrm{fD}}\right| q_{\mathrm{HD}} \frac{A}{a} \quad\left(\mathrm{~N} / \mathrm{mm}^{2}\right) \\
& q_{\mathrm{HD}}=\frac{1}{2} \rho U_{\mathrm{HD}}^{2} \quad\left(\mathrm{~N} / \mathrm{m}^{2}\right)
\end{aligned}
$$

ここで,

$U_{\mathrm{HD}}=49.1(\mathrm{~m} / \mathrm{s}):$ 建物代表高さ $H=200 \mathrm{~m}$ における設計風速 $(\mathrm{L} 1)$ $\rho=1.22\left(\mathrm{~kg} / \mathrm{m}^{3}\right):$ 空気密度

$\hat{C}_{\mathrm{fD}}=-3$ : 設計用帳壁ピーク風力係数（建築物荷重指針・同解説 200410）の帳壁端部に対応する外圧值で内圧 $=0$ と仮定）

$A\left(\mathrm{~m}^{2}\right):$ C.W.一枚あたりの負担面積 $=1.8 \times 4.8=8.64\left(\mathrm{~m}^{2}\right)$

$a\left(\mathrm{~mm}^{2}\right)$ : C.W.一枚あたりの緊結部ボルトの部材総断面積 本検討では設計風速に対するピーク応力の を部材の降伏応力 $\sigma_{\mathrm{y}}$ に倍率を乗じた值となるように条件を設定している。例えば，ボル 卜断面積 $a$ を $=0.5 \sigma_{\mathrm{y}}$ となるように算定する場合, $a$ は次式で与え られる。

$$
a=\frac{P_{\mathrm{D}}}{\sigma_{\mathrm{D}}}=\frac{\left|\hat{C}_{\mathrm{fD}}\right| q_{\mathrm{H}_{\mathrm{D}}} A}{0.5 \sigma_{\mathrm{y}}}\left(\mathrm{mm}^{2}\right)
$$

なお， L2 荷重が L1 荷重の 1.56 倍と寸ると L1 荷重に対しての $\leqq 0.64 \sigma_{\mathrm{y}}$ で設計することが， $\mathrm{L} 2$ 荷重時（L2 風速=62.1m/s）でも検 討部材が降伏しない条件となる。

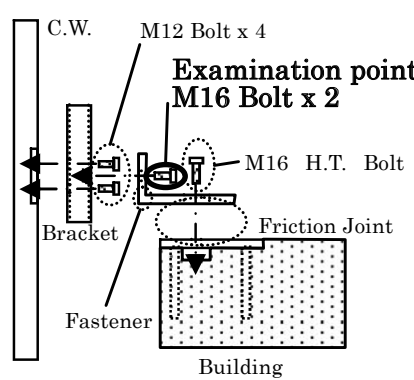

Fig.1 Example of C.W. binder

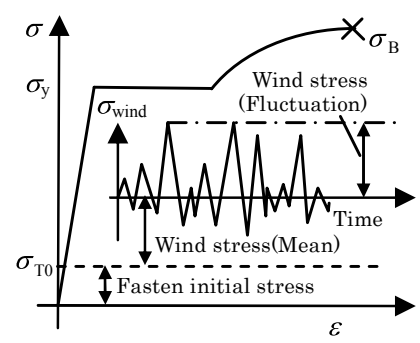

Fig. 2 Image of Bolt Stress under wind loads

\section{3 検討部位に作用する平均風外力について}

地震外力と比較して, 風外力の特徵として作用時間が長いことに 加えて, 荷重に平均成分を有することが挙げられる。Fig. 1 で今回 検討部位として選定したボルトに想定する応力状態の概念図を Fig. 2 に示す。ボルトには施工時の初期張力に対応した初期応力 $\sigma \mathrm{T} 0$ が存在している。構造骨組部材の接合に用いられる高力ボルトの場 合は施工時にボルト締め付けトルクの管理が義務付けられており, 比較的高い初期応力が導入されるが, 外装材を留める一般のボルト ではトルクの管理值等は設定されていない。

無風時のボルトには施工時の初期応力 $\sigma \mathrm{T} 0$ が作用し, 平均值を有 寸る変動風力を受ける際にはさらに平均風力十変動風力に対応した 応力が発生する。本検討では不確定な值である無風時の初期応力 $\sigma \mathrm{T} 0$ は 0 と仮定し, 外力として平均風力十変動風力が作用する時の疲労 を検討することとした。また，帳壁の外圧が正となって帳壁が支持 部材に押し付けられる場合, 圧縮力は検討対象のボルトではなく Fig. 1 中の L 字型部材が主に負担することになるが，本検討では簡 単のために圧縮力についてもボルトが負担すると仮定した。

\section{4 風洞実験概要}

参考文献 11）に示寸建物単体模型を用いた風洞実験で得られた変 動風圧を疲労評価用の外圧時刻歴として用いる。Fig. 3 に風圧実験 模型の概要を示す。風圧模型は縮尺 $1 / 500$ と仮定した正方形断面角 柱(幅 $B=D=0.1 \mathrm{~m}$, 高さ $H=0.4 \mathrm{~m}$ )である。風圧測定点は 476 点設け ている。実験気流はFig. 4 に示寸ように地表面粗度区分 IIIにほぼ対 応するものであり，模型代表高さにおける乱れのスケール $L_{\mathrm{H}}$ は $0.47 \mathrm{~m}$ であった。変動風圧の計測条件は, サンプリング周波数 $1,000 \mathrm{~Hz}$ ，アナログローパスフィルタ $400 \mathrm{~Hz}$ ，データ個数 $n$ data $=32,768$ 個とし, 計測した風圧データは導圧チューブの伝達特 性をナイキスト周波数まで補正した。さらに，各計測点での風圧波 形を実 POD 解析 ${ }^{12}$ )を用いて $350 \mathrm{~Hz}$ 以上の周波数成分を補正(外挿) した時刻歴データを用いた。実験風速 $U_{\mathrm{Hexp}}=12 \mathrm{~m} / \mathrm{s}$ で計測した風圧 の統計值等を求める際の風速として L1 設計風速 $U_{\mathrm{HD}}=49.1 \mathrm{~m} / \mathrm{s}$ を用 いたので, 実験で得られた全データ長は実大相当で 66.7 分となる。 外圧係数のピーク值評価に用いる平均化時間 (移動平均個数) は C.W. の長さを基に TVL 法 ${ }^{13)}$ を参考に $U_{\mathrm{HD}}$ 時には実大相当 $0.25 \mathrm{sec}(2$ 個 $)$ とした。検討においては全ての疲労検討用風速 $U_{\mathrm{H}}$ に対して移動平 均個数 2 個とした同一の波形を採用した。これは, TVL 法に基づい 
た場合, 風速が変化するとピーク值の評価時間も変化して移動平均 に用いるデータ個数は変化しないこと, 全検討風速 $U_{\mathrm{H}}$ に対して実 大相当 $0.25 \mathrm{sec} の$ 移動平均処理を施すには実験におけるサンプリン グ周波数の分解能が不足することの 2 つの条件を考えて採用した処 置である。

実験風向 $\theta$ はFig. 3 に示すように $0^{\circ} \sim 90^{\circ}$ ( $5^{\circ}$ ピッチ)の 19 風向 であるが，模型の対称性を考慮して $0^{\circ} \sim 355^{\circ}$ の 72 風向のデータ に変換して検討に用いた。

検討に用いた帳壁の外圧係数時刻歴 $C_{\mathrm{pe}}(i)$ は模型代表高さ $H$ にお ける実験風速に対応した基準圧を用いて算定した（ $i$ は実験で得ら れた時刻歴のデータステップ( $i=1, n$ data $)$ を示す)。検討用の風力係 数時刻歷 $C_{\mathrm{f}}(i)$ は, 外圧係数 $C_{\mathrm{pe}}(i)$ の時刻歴および内圧係数 $C_{\mathrm{pi}}(i)$ の時 刻歴（本検討では 0 と仮定）より下式で与えた。

$$
C_{\mathrm{f}}(i)=C_{\mathrm{pe}}(i)-C_{\mathrm{pi}}(i)
$$

風力係数の統計值は, 風速 $U_{\mathrm{HD}}$ に対して実大 10 分間相当 6 回の アンサンブル平均値を採用した。このようにして求めた風力係数時 刻歴 $C_{\mathrm{f}}(i)$ の平均值,標準偏差, 最大值, 最小值を $C_{\mathrm{fmean}}, C_{\mathrm{fsD}}, C_{\mathrm{fmax}}, C_{\mathrm{fmin}}$ と表す。また, 実験風向 $\theta$ に対応したそれぞれの值を $C_{\mathrm{f}}(\theta, i), C_{\text {fmean }}(\theta)$, $C_{\mathrm{fSD}}(\theta), C_{\mathrm{fmax}}(\theta), C_{\mathrm{fmin}}(\theta)$ と表す。

\section{5 疲労特性}

検討部位のボルトは強度区分 4.6 の鋼製ボルトを想定し，JIS $\mathrm{B} 1051$ 14)に示される最小引張強さ $\sigma \mathrm{B}=400 \mathrm{~N} / \mathrm{mm}^{2}$, 降伏応力 $\sigma_{\mathrm{y}}=240 \mathrm{~N} / \mathrm{mm}^{2}$ の值を採用する。強度区分 4.6 の鋼製ボルトの基本疲 労強度は, 建築物の疲労設計を定めた日本鋼構造協会「鋼構造物の 疲労設計指針・同解説 $\left.{ }^{15}\right) 」($ 以下, 疲労設計指針) および建築や機

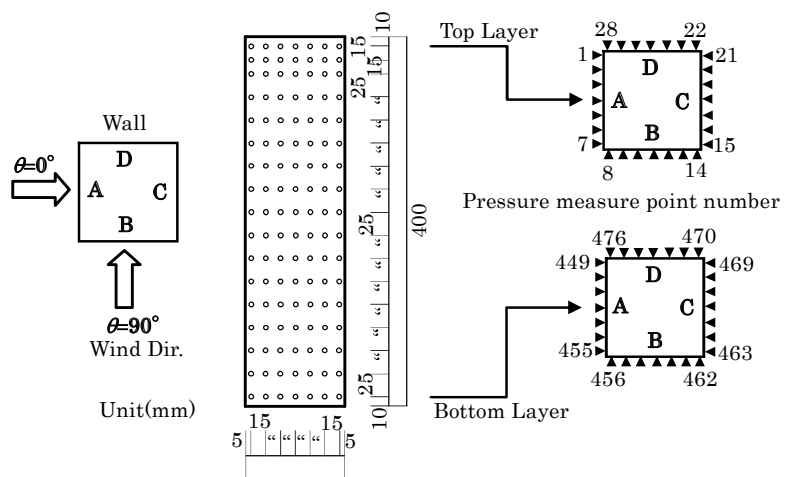

Fig.3 Wind tunnel test model (1:1:4 Square Cylinder)

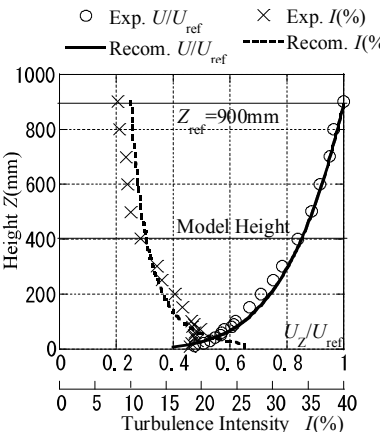

(a) Vertical profiles of mean wind velocity and turbulence intensity

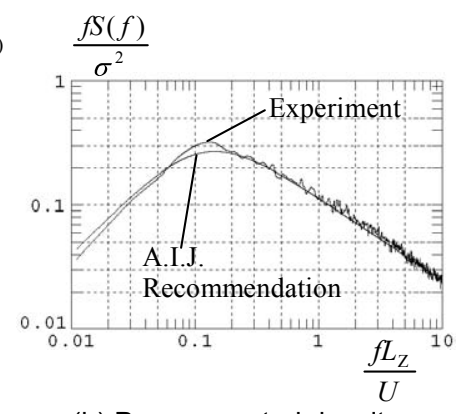

(b) Power spectral density of wind speed
Fig.4 Characteristics of wind tunnel flow
械に関する規・基準では与えられていない。また，参考文献 16)で は, M8〜M16 の呼び径範囲で強度区分 4.8，6.8，8.8 の疲労強度は 強度区分による差が比較的小さく, $72 \sim 46 \mathrm{~N} / \mathrm{mm}^{2}$ の值が図示され ている。以上を鑑み, 本論文では基本疲労強度については疲労設計 指針に示される「直応力を受ける高力ボルト(K-4)」の值を準用する こととし，関連する変数を以下のように定義する。

$\sigma_{\mathrm{f}}\left(\mathrm{N} / \mathrm{mm}^{2}\right)$ : 検討部材の $2 \times 10^{6}$ 回基本疲労強度 $=65 \mathrm{~N} / \mathrm{mm}^{2}$ $\sigma_{\text {cut }}\left(\mathrm{N} / \mathrm{mm}^{2}\right)$ : 応力範囲の打ち切り限界 (変動振幅 $=21 \mathrm{~N} / \mathrm{mm}^{2}$ )

$m:$ 疲労曲線の傾きを示す定数 $=5$

$C_{0}$ : 疲労曲線を示すための定数 $=2 \times 10^{6} \times \sigma_{\mathrm{f}}{ }^{m}\left(\right.$ 回 $\left.\left(\mathrm{N} / \mathrm{mm}^{2}\right)^{m}\right)$

疲労設計指針に示される様々な部位における $m$ の值は 3 または 5 であり，本論文では $m$ の影響を見るため $m=3$ としたケースについ ても追加検討寸る。また, 忘力範囲の打ち切り限界 $\sigma_{\mathrm{cut}}$ は, 実験值 に基づく検討でのみ考慮した。

\section{6 応力係数時刻歴による疲労損傷率算定}

疲労設計において基本疲労強度は応力值（単位： $\mathrm{N} / \mathrm{mm}^{2}$ ) として 与えられるため, 通常は検討部材に発生する応力時刻歷から照査用 応力振幅や回数を算定して疲労損傷率を算定するが，本論文では検 討用応力を風圧係数と同様に無次元化した応力（以下，応力係数） で疲労損度率を算定することとした。応力係数を導入することによ り，2.7 節に概要を述べる実験值からの近似式に将来的な汎用性を 持たせた。さらに，本論文では風力の方向と発生応力の方向を明確 に対応させる係数として以下に示す $C_{\mathrm{DIR}}$ を導入し, 様々な部位の検 討に対応可能とした。

検討部材に発生する疲労検討用応力時刻歴 $\sigma(i)$ の算定では, 風力 係数 $C_{\mathrm{f}}(i)$ の符号（風力の作用方向）と，検討部材に発生する応力の 方向（符号）には十分注意する必要がある。Fig. 1 に示すような納 まりの場合, 帳壁が負圧で建物外部方向に引っ張られると, 疲労検 討部位のボルトを軸方向に伸ばす方向に外力が作用し，ボルトに発 生する応力は正の値(引っ張り)となる。この場合, 風力の符号(-)と 部材発生応力 $(+)$ の符号が反転しているので $C_{\mathrm{DIR}}=-1$ とし, 逆に風力 の符号と部材発生応力が同符号の場合は $C_{\mathrm{DIR}}=+1$ とする。

$C_{\mathrm{DIR}}$ を考慮した $\sigma(i)$ を下式のように定義する（i は実験で得られた 時刻歴のデータステップ $(i=1$, ndata $)$ を示す $)$ 。

$$
\begin{aligned}
& \sigma(i)=\frac{P(i)}{a}=C_{\mathrm{DIR}} C_{\mathrm{f}}(i) q_{\mathrm{H}} \frac{A}{a}\left(\mathrm{~N} / \mathrm{mm}^{2}\right) \\
& q_{\mathrm{H}}=\frac{1}{2} \rho U_{\mathrm{H}}^{2}\left(\mathrm{~N} / \mathrm{m}^{2}\right)
\end{aligned}
$$

ここで,

$P(i)(\mathrm{N})$ : 変動風力によりボルトに発生する軸力時刻歷 $U_{\mathrm{H}}(\mathrm{m} / \mathrm{s})$ : 建物高さ $H$ における疲労検討用風速

ここで, 応力時刻歴 $\sigma(i)$ を応力係数 $C_{\sigma}(i)$ に無次元化するための変 数として式(8)の fact を導入する。本論文では設計応力の を部材の $\sigma_{\mathrm{y}}$ に対する倍率で規定しているので, 例えばの $=0.5 \sigma_{\mathrm{y}}$ の場合, 式 $(8)$ の $a$ に式(4)を代入して式(8')のように fact 設定できる。

$$
\text { fact }=q_{\mathrm{H}} \frac{A}{a}\left(\mathrm{~N} / \mathrm{mm}^{2}\right)
$$

$$
\text { fact }=q_{\mathrm{H}} \frac{A}{a}=\frac{q_{\mathrm{H}}}{q_{\mathrm{HD}}} \frac{0.5 \sigma_{\mathrm{y}}}{\left|\hat{C}_{\mathrm{fD}}\right|} \quad\left(\mathrm{N} / \mathrm{mm}^{2}\right)
$$


なお, $q_{\mathrm{H}}$ と $q_{\mathrm{HD}}$ は 2.1 節に示す $U_{\mathrm{H}}$ と $U_{\mathrm{HD}}$ に対応する速度圧である。 fact を導入することにより式(6)は式(9)の表現となる。

$$
C_{\sigma}(i)=\frac{\sigma(i)}{\text { fact }}=C_{\mathrm{DIR}} C_{\mathrm{f}}(i)
$$

2.5 節で設定した疲労特性値も factを用いて規準化する。

$$
\begin{aligned}
& C_{\text {oB }}=\frac{\sigma_{\mathrm{B}}}{f a c t}, C_{\text {of }}=\frac{\sigma_{\mathrm{f}}}{f a c t}, C_{\text {oy }}=\frac{\sigma_{\mathrm{y}}}{f a c t}, C_{\text {ocut }}=\frac{\sigma_{\mathrm{cut}}}{f a c t} \\
& C_{C 0}=2 \times 10^{6} \times\left(C_{\text {of }}\right)^{m} \quad \text { (回) }
\end{aligned}
$$

ここで, 設計風速 $U_{\mathrm{HD}}$ の fact に対応した式(10),(11)の值を以下の 記号で定義する。

$$
C_{\sigma \mathrm{B}}\left(U_{\mathrm{HD}}\right), C_{\sigma \mathrm{of}}\left(U_{\mathrm{HD}}\right), C_{\text {oy }}\left(U_{\mathrm{HD}}\right), C_{\sigma \mathrm{cut}}\left(U_{\mathrm{HD}}\right), C_{C 0}\left(U_{\mathrm{HD}}\right)
$$

さらに, 疲労損傷率算定に用いる風向 $\theta$ の疲労検討用応力係数 $C_{\sigma}(i)$ の統計值を Fig. 3 で定義した実験風向 $\theta$ の風力係数 $C_{\mathrm{f}}(i)$ の統計 值（設計風速 $U_{\mathrm{HD}}$ に対応したアンサンブル平均值）に風向 $\theta$ の表記 を追加して以下のように定義する。

$$
\begin{aligned}
& C_{\sigma \operatorname{mean}}(\theta)=C_{\mathrm{DIR}} C_{\mathrm{fmean}}(\theta), \quad C_{\sigma \mathrm{SD}}(\theta)=C_{\mathrm{fSD}}(\theta) \\
& C_{\sigma \max }(\theta)=\max \left(C_{\mathrm{DIR}} C_{\mathrm{f} \text { max }}(\theta), \quad C_{\mathrm{DIR}} C_{\mathrm{f} \text { min }}(\theta)\right) \\
& C_{\sigma \min }(\theta)=\min \left(C_{\mathrm{DIR}} C_{\text {f } \max }(\theta), \quad C_{\mathrm{DIR}} C_{\mathrm{f} \min }(\theta)\right)
\end{aligned}
$$

また, 応力係数の変動成分 $C_{\text {ofluct }}(\theta)$ を下式で定義する。

$$
C_{\text {ofluct }}(\theta)=\max \left(\left|C_{\text {omax }}(\theta)-C_{\text {omean }}(\theta)\right|,\left|C_{\text {omin }}(\theta)-C_{\text {omean }}(\theta)\right|\right)
$$

次に, 疲労検討用応力係数時刻歴 $C_{\sigma}(i),(i=1, n$ data $)$ からレイン フロー法 ${ }^{15)}$ により疲労検討用応力係数の振幅 $C_{\sigma \max }(j)$ および $C_{\sigma \min }(j)$ $(j=1$, namp $)$ を抽出し, 丙振り応力係数の振幅 $C_{\sigma a}(j)$ と平均值 $C_{\sigma \mathrm{m}}(j)$ を下式により算定する。本論文では namp 個の $C_{\text {ба }}(j)$ および $C_{\text {б }}(j)$ を $C_{\text {ба }}(j)$ のきさにより降順に並び替えた值（以下，ソート值）を用い るので $j$ は両振り応力係数振幅 $C_{\text {бa }}(j)$ の順位を示している。

$$
\begin{gathered}
C_{\sigma \mathrm{a}}(j)=\frac{C_{\sigma \max }(j)-C_{\sigma \min }(j)}{2} \\
C_{\sigma \mathrm{m}}(j)=\frac{C_{\sigma \max }(j)+C_{\sigma \min }(j)}{2}
\end{gathered}
$$

Fig. 5 に $C_{\mathrm{DIR}}=-1$ とした場合の応力係数時刻歴 $C_{\sigma}(i)$ (データ個数 ndata $=400 ）$ とレインフロー法により抽出された $C_{\sigma \mathrm{m}}(j), C_{\sigma \mathrm{a}}(j)$, $C_{\sigma \max }(j), C_{\sigma \min }(j)$ の例(ソート值)を示寸。400step の時刻歴波形から 抽出された応力係数振幅の個数は namp $=50$ 個であった。ここで着目 す心゙きは, 抽出してソートされた最大の $C_{\sigma \mathrm{a}}(j=1)$ に対応する $C_{\sigma \max }(1)$ および $C_{\sigma \min }(1)$ は時刻歴波形の最大值と最小值に対応しているこ とである。当然, 時刻歴波形の性状によっては必ずしもこのような 対応にはならないが, 外装材に作用寸る負の風力 $\left(C_{\mathrm{DIR}}=-1\right.$ の本検 討では正側の応力）のピーク波形がパルス状の性状を示すことが多 いことを考えると, $C_{\sigma \max }(1)$ が時刻歴波形の最大值に対応する可能 性は高い。また, 50 個抽出された振幅のうち $j=21$ 以降の応力係数 振幅の $C_{\sigma \mathrm{a}}(j)$ は值が小さく(Fig. $5(\mathrm{~b})$ 中では, $C_{\sigma \mathrm{a}}(j)$ の縦線がほとんど 見えず $C_{\sigma \mathrm{m}}(j)$ の記号のみが見える), 疲労損傷率は応力係数振幅の $m$ 乗に比例することを考えると, 損傷率全体に影響を与える上位から の振幅の数は 50 よりも小さくなると考えられる。さらに, Fig. 5 (a) の時刻歷 $C_{\sigma}(i)$ の平均値は図中に一点鎖線で示すように 0.67 である が, Fig. 5(b)の応力係数振幅の平均值 $C_{\sigma \mathrm{m}}(j)$ は式(16)に示すように $C_{\sigma \max }(j)$ および $C_{\sigma \min }(j)$ の平均值であるため, $C_{\sigma \mathrm{m}}(1)=1.05, C_{\sigma \mathrm{m}}(9)=0.31$
のように元波形からの平均值のずれが大きい振幅もある。

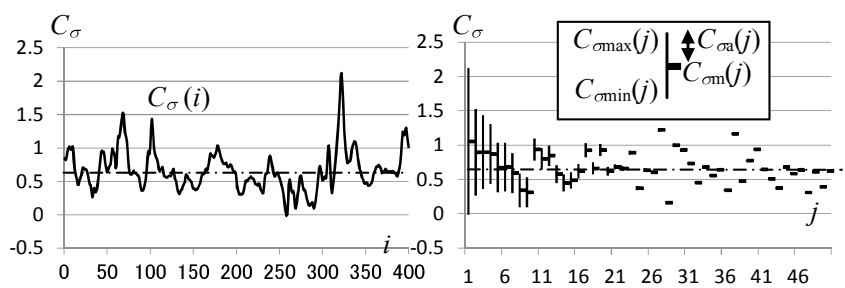

(a) Stress coef. time history

Fig 5 Example of stress coef. an from stress coef. time history by rainflow method

Fig. 5 (b) に示す応力係数振幅 $C_{\text {бa }}(j)$ にその平均成分 $C_{\sigma \mathrm{m}}(j)$ を考慮す るために，ボルトの引張強さ $C_{\sigma \mathrm{B}}$ を用いて式(17)に示寸修正 Goodman 法により平均成分の影響を考慮した両振り応力係数振幅 $C_{\text {ow }}(j)$ を算定する。

$$
C_{\text {ow }}(j)=C_{\sigma \mathrm{a}}(j)\left(1-\frac{C_{\text {om }}(j)}{C_{\text {oB }}}\right)^{-1}
$$

修正 Goodman 法による $C_{\sigma \mathrm{w}}(j)$ の算定の概念を Fig. 6 に示す。平 均値を有する応力時刻歴からレインフロー法により抽出された最大 の振幅をFig. 6 (a) 中の Case1 $\left(C_{\text {бa }},+C_{\sigma \mathrm{m}}\right)$ とすると，同じ波形の 正負を反転した時刻歴から抽出された最大の振幅は図中の Case2 $\left(C_{\sigma \mathrm{a}},-C_{\sigma \mathrm{m}}\right)$ となり， $C_{\mathrm{\sigma}}$ は同一の值で $C_{\sigma \mathrm{m}}$ の符号が反転してい る。Case 1 と Case 2 を比較すると疲労損傷評価に用いる両振り応力 係数振幅 $C_{\sigma \mathrm{w} 1}$ と $C_{\sigma \mathrm{w} 2}$ の值には差が生じる。Fig. $6(\mathrm{~b})$ は降伏曲面上 でCase1,Case2 の補正方法を示したものである。Fig. 6 (a)に示すよ うに同一波形に対して $C_{\mathrm{DIR}}= \pm 1$ の検討をする場合には, どちらかの $C_{\mathrm{DIR}}$ で算定した結果の $C_{\sigma \mathrm{m}}(j)$ の符号を正負反転して用いればよい。

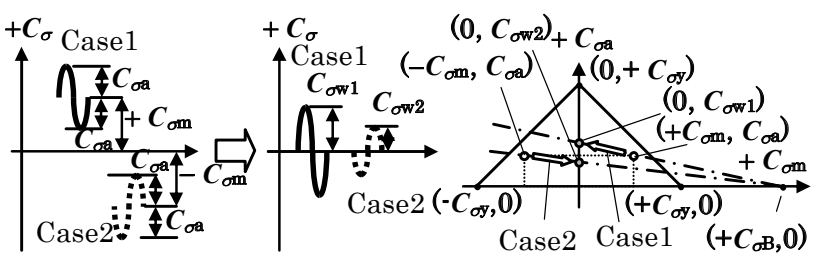

(a) Wave form

(b) Fatigue limit curve

Fig. 6 Stress coef. amplitude correction image by modified Goodman method

こうして得られた $C_{\sigma \mathrm{w}}(j)$ より 2.5 節で設定した疲労検討用の応力 係数 $C_{C 0}, m$ を用いて, 振幅 1 個あたりのマイナー則による疲労損 傷率 $D(j)$ を下式で算定する。

$$
D(j)=\frac{C_{\sigma w}(j)^{m}}{C_{C 0}}=\frac{1}{C_{C 0}}\left\{C_{\sigma a}(j) \times\left(1-\frac{C_{\text {om }}(j)}{C_{\sigma B}}\right)^{-1}\right\}^{m} \quad(1 / \text { 回 })
$$

疲労損傷率の算定に打ち切り応力 $C_{\text {ocut }}$ を考慮する場合は, 以下の 条件も考慮する。

$D(j)=0 \quad\left(\right.$ for $\left.C_{\text {ow }}(j)<C_{\text {ocut }}\right)$

こうして, $j$ で表される各振幅の疲労損傷率 $D(j)$ が求まる。検討 用の全データ $(j=1$, namp $)$ に対応する疲労損傷率 $D_{\text {all }}$ は下式となる。

$$
D_{\text {all }}=\sum_{j=1}^{n a m p} D(j)
$$


さらに, 疲労損傷率算定に用いた応力振幅 $D(j)$ の数（ただし， $D(j)>0)$ を $N_{\text {all }}$ としてカウントする。

疲労算定時風速 $U_{\mathrm{H}}$ の全データ長に対応する実大相当時間を $T_{\text {all }}$ (sec) とすると, 実大 10 分間 $(600 \mathrm{sec})$ 相当の疲労損傷率 $D_{10}$ と算定 に用いた振幅の数 $N_{10}$ は下式で表される。

$$
D_{10}=D_{\text {all }} \frac{600}{T_{\text {all }}} \quad （ 1 / \text { 回）， } N_{10}=N_{\text {all }} \frac{600}{T_{\text {all }}} ＼mathrm{~ （ 回 ） ~}
$$

$D_{10}, N_{10}$ の評価に風圧係数の統計值と同様なアンサンブル平均を 採用しなかったのは, 風速 $U_{\mathrm{H}}$ を徐々に変化させた場合にアンサン ブル回数（整数）の切り替えによって有効なデータ個数が変化し, 損傷率の值が不連続となるのを避けるためである。なお, 設計風速 $U_{\mathrm{HD}}$ に対応した $T_{\text {all }}$ を $T_{\mathrm{all}}\left(U_{\mathrm{HD}}\right)$ と表記する。

\section{7 風向 - 風速別の 10 分間疲労損傷率近似值算定の流れ}

本論文の目的の 1 つは代表点における風向・風速別の 10 分間疲 労損傷率の実験值（風圧統計値）に基づいた算定方法を示すことで ある。検討結果である実験結果の分析やそれに基づいた諸変数の近 似の検討は 3 章で述べるが, 本節では順序が前後するが, 検討結果 に基づいて構築した上記の算定方法の流れの全体像を先に示す。

前節で展開した 10 分間疲労損傷率 $D_{10}$ は, 暗㷛の条件として特定 の風向 $\theta$ と特定の検討風速 $U_{\mathrm{H}}$ について算定したものであるが，本節 では風向 $\theta$ と検討風速 $U_{\mathrm{H}}, U_{\mathrm{HD}}$ をパラメータとする $D_{10}$ の近似值を, 風洞実験結果から精算した疲労損傷率の算定結果を基に設定した 10 分間の風向 - 風速別疲労損傷率の近似式 $d_{10}$ (風速, 風向) として下 式のように表記する。

$d_{10}\left(U_{\mathrm{H}}, \theta\right)=d_{10}\left(U_{\mathrm{HD}}, \theta_{\mathrm{ref}}\right) \times u f a c t\left(U_{\mathrm{H}}\right) \times \operatorname{tfact}(\theta)$

ここで,

$d_{10}\left(U_{\mathrm{H}}, \theta\right)$ : 風向 $\theta$ ・風速 $U_{\mathrm{H}}$ に対応した 10 分間疲労損傷率近似值

$\theta_{\mathrm{ref}}$ : 風洞実験結果から求めた $d_{10}\left(U_{\mathrm{HD}}, \theta\right)$ が全風向中で最大とな る風向 $\theta$ (実験值より決定 : 3.1 節，Table 1, Table A 参照)

$d_{10}\left(U_{\mathrm{HD}}, \theta_{\mathrm{ref}}\right)$ : 設計風速 $U_{\mathrm{HD}}$, 風向 $\theta_{\mathrm{ref}}$ の条件で風洞実験結果を 近似した 10 分間疲労損傷率 $D_{10}$ の全風向中最大值(実験值の近 似値 : 以下の式(23)でさらに詳細に展開)

ufact $\left(U_{\mathrm{H}}\right)$ : 設計風速 $U_{\mathrm{HD}}$, 風向 $\theta_{\mathrm{ref}}$ で算定された $d_{10}\left(U_{\mathrm{HD}}, \theta_{\mathrm{ref}}\right)$ を 検討風速 $U_{\mathrm{H}}$ に対応した值に変換する係数。(実験值の近似值 : 3.5 節，式(32),Table 5 参照)

tfact $(\theta)$ : 全風向中最大の $d_{10}\left(U_{\mathrm{HD}}, \theta_{\mathrm{ref}}\right)$ を検討風向 $\theta$ に対応した 值に変換する係数。(実験值の近似值 : 3.6 節, 式(34), Table 6 参照)

式(22)中の $d_{10}\left(U_{\mathrm{HD}}, \theta_{\mathrm{ref}}\right)$ は, 打ち切り応力を考慮しない場合, 式 (17)〜(21)をまとめた下式で近似する。

$$
\begin{aligned}
& d_{10}\left(U_{\mathrm{HD}}, \theta_{\mathrm{ref}}\right)=\frac{600}{T_{\mathrm{all}}\left(U_{\mathrm{HD}}\right)} \times \\
& \frac{1}{C_{C_{0}}\left(U_{\mathrm{HD}}\right)} \sum_{k=1}^{k \mathrm{kal}}\left\{C_{\sigma_{\mathrm{a}}}\left(\theta_{\mathrm{ref}}, k\right) \times\left(1-\frac{C_{\sigma_{\mathrm{m}}}\left(\theta_{\mathrm{ref}}, k\right)}{C_{\sigma_{\mathrm{B}}}\left(U_{\mathrm{HD}}\right)}\right)^{-1}\right\}^{m} \times d \text { correc }
\end{aligned}
$$

ここで,

$C_{\sigma a}\left(\theta_{\mathrm{ref}}, k\right)$ : 式(15)の疲労損傷率を算定する応力振幅 $C_{\sigma \mathrm{a}}(j)$ の実験值 を近似した值で, 風向 $\theta_{\mathrm{ref}}$ に対応する表記を追加し振幅順位を表 寸添字は実験值 $j$ を縮約した $k$ に置き換えた。下記の $k_{\text {all }}$ と風向 $\theta_{\text {ref }}$ に対応したTable 3 の係数 $f_{\mathrm{a}}, f_{\mathrm{b}}$ および式(13),(14)の $C_{\text {ffluct }}\left(\theta_{\text {ref }}\right)$
から式(28)により算定する。(実験值の近似值: 3.4 節(a)(c),Table $\mathrm{A}$ 参照)

$C_{\text {orm }}\left(\theta_{\mathrm{ref}}, k\right)$ : 式(16)の疲労損傷率を算定する応力振幅の平均值 $C_{\text {or }}(j)$ の実験值を近似した值で, 表記の変更(風向 $\theta_{\mathrm{ref}}$ 対応, 添字 $k$ ) は $C_{\sigma \mathrm{a}}\left(\theta_{\mathrm{ref}}, k\right)$ と同じ。 $C_{\sigma \mathrm{a}}\left(\theta_{\mathrm{ref}}, k\right)$ と下記の $k_{\mathrm{all}}$ および式(13)の風向 $\theta_{\mathrm{ref}}$ の

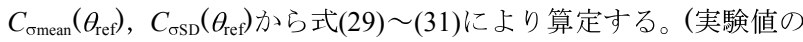
近似值 : 3.4 節(b)(c) ,Table A 参照)

$k_{\text {all }}($ 回 $)$ : 疲労損傷率近似值を算定する応力振幅の数で任意に決定 するが $k_{\text {all }} \geqq 392$ を推奨。(下記 $T_{\text {all }}\left(U_{\mathrm{HD}}\right)$ の解説, 3.3 節参照)

dcorrec : $d_{10}\left(U_{\mathrm{HD}}, \theta_{\mathrm{ref}}\right)$ の実験值と近似值の誤差を補正する係数(3.4 節,Table 4 参照)

$C_{C 0}\left(U_{\mathrm{HD}}\right), C_{\mathrm{BB}}\left(U_{\mathrm{HD}}\right)$ : 式(12)に示寸設計風速 $U_{\mathrm{HD}}$ に対応した疲労特 性值。

$T_{\mathrm{all}}\left(U_{\mathrm{HD}}\right)(\mathrm{sec})$ : 式 $(21)$ に示寸設計風速 $U_{\mathrm{HD}}$ に対応した数值。 近似式を用いた検討では任意に設定することになるが，上記の $k_{\mathrm{all}} \geqq 392$ の条件を満たすように式(25),(26)から決定する。本論 文における検討例では，近似式の検討に用いた $U_{\mathrm{HD}}$ と風洞実験 值のデータ個数 ndata に対応する值(66.7 分 $\rightarrow$ 約 $4,000 \mathrm{sec}$ ) とした。

なお，本論文の範囲外となるが，本研究の最終目的とする風向風 速頻度を考慮した疲労損傷率算定では，疲労検討期間中に発生する 風速 $U_{\mathrm{Hi}}$ 風向 $\theta \mathrm{i}$ に対応した $d_{10}\left(U_{\mathrm{Hi}}, \theta \mathrm{i}\right)$ を総和した $D_{\mathrm{all}}=\sum\left\{d_{10}\left(U_{\mathrm{Hi}}, \theta \mathrm{i}\right)\right\}$ が最終目的と寸る疲労損傷率となる。また，式(11)および式(23)か ら明らかなように, $C_{C 0}\left(U_{\mathrm{HD}}\right)$ に含まれる $2 \times 10^{6}$ 回基本疲労強度 $\sigma_{\mathrm{f}}$ 以 外の疲労算定条件が同一であれば, $\sigma_{\mathrm{f}}$ を用いて算定した損傷率を $D_{\mathrm{all}}$ とすると, 異なった $\sigma_{\mathrm{f}}^{\prime} て ゙$ 算定した疲労損傷率 $D_{\mathrm{all}}{ }^{\prime}$ は下式で換算する ことができる。

$$
D_{\text {all }}=D_{\text {all }}\left(\sigma_{\mathrm{f}} / \sigma_{\mathrm{f}}^{\prime}\right)^{m}
$$

\section{3. 検討結果と考察}

本章では， 2.6 節で示した疲労損傷率の算定方法を用いて実大 10 分間相当の $D_{10}$ の值やその分布状況および特性等を検討する。検討 においては基本的に検討風速 $U_{\mathrm{H}}=U_{\mathrm{HD}}$ とした。また 3.3 節以降では 風洞実験結果の近似式をの $=0.8 \sigma_{\mathrm{y}}$ のケースについて策定し，実験に よる算定結果と近似式による算定結果を比較・検討寸る。

\section{1 疲労損傷率 $D_{10}$ の検討}

ここでは，実大 10 分間相当の $D_{10}$ を算定した結果を検討する。算 定条件は $U_{\mathrm{H}}=U_{\mathrm{HD}}=49.1 \mathrm{~m} / \mathrm{s}, \sigma \mathrm{D}=0.8 \sigma_{\mathrm{y}}, C_{\mathrm{DIR}}=-1, m=5(\mathrm{~K}-4)$ とした。 Fig. 7 に壁面 $\mathrm{A} ， \mathrm{~B} ， \mathrm{C}$ における風向 $0^{\circ}$ の $D_{10}$ 分布状況を示寸。ま た，実験模型の対称性を考慮した全風向中の $D_{10}$ の最大值の分布状 況を Fig. 8 に示寸。疲労損傷率は，基本的に応力時刻歴の変動成分 に基づく值であるので, 風圧統計值 $C_{\text {ofluct }}$ の分布に傾向が似ているが, スペースの都合上，ここでは $C_{\text {flluct }}$ の分布図は省略する。

本検討では, Fig. 7 に示寸ように風向 $0^{\circ}$ 近傍において風向側壁 面 $\mathrm{B}$ で疲労損傷率 $D_{10}$ が大きな值となり, 全風向を考慮しても疲労 損傷率が大きな值となる領域から壁面 $\mathrm{B}$ 上の 3 つの代表点 $\alpha$ (計測 点番号 8), $\beta$ (計測点番号 210),$\gamma($ 計測点番号 429) を選定して疲 労損傷率および外力の特性を詳細に検討する。

代表点 $\alpha$ と 離してカルマン渦が発生し，大きな負圧が発生する領域であり，文 献によると風向側面上に発生する円錐状の渦により局所的に大きな 


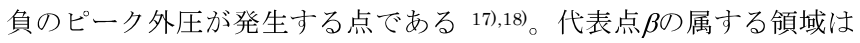
風向 $\theta=0^{\circ}$ 近傍において風上面端部で剥離した剥離せん断層が壁面 に再付着する部分である。参考として式(13),(14)で定義した代表点 $\beta$, の応力係数 $C_{\sigma}(i)$ 統計值の風向による変化を Fig. 9 に示寸。

Fig. 10 に代表点 $\beta, \quad \gamma$ における $D_{10}$ の風向による変化を示す。図中 には無次元打切り応力 $C_{\text {out }}$ を考慮した場合と考慮しない場合の結果 が示されている。代表点の $D_{10}$ 值が大きくなるのは, 代表点が位置 する壁面 $\mathrm{B}$ が風方向に対して側面となる風向(壁面 $\mathrm{A}$ または $\mathrm{C}$ が風 方向に直角となる風向 $0^{\circ}$ および $\left.180^{\circ}\right)$ の近傍である。このことは 上で述べたように風方向に対して側面となる壁面 $\mathrm{B} て ゙$ 発生する円錐 状の渦や, 剥離せん断層の再付着領域でピーク風力係数の絶対值が 大きな值となることに対応している。なお, 壁面 $\mathrm{B}$ 上の全計測点の $D_{10}$ 值の風向による変化は, 高さ方向に $D_{10}$ 值の大小の差はあるもの の, 平面位置が同じ点では風向による変化については同様な性状と なっている 19)。

Fig. 11 に代表点 $\beta, \gamma$ の疲労損傷率算定に用いた振幅の数 $N_{10}$ の風 向による変化を,Fig. 10 と同様に打切り応力を考慮した場合と考慮 しない場合について示す。Fig. 10 と Fig. 11 で打切り応力考慮の有 無に着目すると, $N_{10}$ の值は打切り応力考慮なしで $573 \sim 993$ 回なの に対し, 打切り応力を考慮した場合は全風向中における $N_{10}$ の最大 值が 74 回と大きく減少する。一方, $D_{10}$ の值は $D_{10}>5 \times 10^{-8}$ の領域 では打切り応力考慮の有無でほとんど変わらない。これはFig. 5 (b) に示すように，検討点の $D_{10}$ に有効な（支配的な）応力振幅の数は 比較的少ない $C_{\sigma a}(j)$ の上位振幅 $(j$ が小さい振幅)でほぼ決定されてお り, $C_{\sigma_{a}}(j)$ が小さな值となる大多数の振幅は, 検討点の $D_{10}$ にほとん ど影響を与えないことを示している。

\section{2 疲労損傷率の值と, 損傷率に与える応力の平均成分の影響}

本節では Fig. 6 に示寸修正 Goodman 法における平均応力成分が 疲労損傷率 $D_{10}$ に与える影響を検討する。算定条件は $U_{\mathrm{H}}=49.1 \mathrm{~m} / \mathrm{s}$, $\sigma_{\mathrm{D}}=\left[0.5 \sigma_{\mathrm{y}}, \quad 0.8 \sigma_{\mathrm{y}}, 1.0 \sigma_{\mathrm{y}}\right], C_{\mathrm{DIR}}=[+1,-1], m=[3,5]$, 打切り応 力考慮なしとした。全風向中の最大の $D_{10}$ 值とその発生風向 $\theta_{\mathrm{ref}}$ (deg.) をTable 1 に示す。表中の損傷率が最大となるのは, $\sigma \mathrm{D}=1.0 \sigma_{\mathrm{y}}$,
$C_{\mathrm{DIR}}=-1, \quad m=5$ の代表点 $\gamma$ で $D_{10}=2.83 \times 10^{-3}$ であった。この $D_{10}$ 值が 1 になるためには，建物供用期間中に $U_{\mathrm{H}}=49.1 \mathrm{~m} / \mathrm{s}$ の風が $\theta_{\mathrm{ref}}=355 \mathrm{deg}$ で総計59時間吹く必要があり, この $D_{10}$ 值は疲労設計上小さめの值 と考えられる。この值は疲労特性の $\sigma_{\mathrm{f}}=65 \mathrm{~N} / \mathrm{mm}^{2}$ に基づく值であり 仮に $\sigma_{\mathrm{f}}=45 \mathrm{~N} / \mathrm{mm}^{2}$ と仮定して式 $(24)$ から $D_{10}$ を算定すると $D_{10}=1.78 \times 10^{-2}$ となり, $D_{10}=1$ になるため必要な風が吹く時間は, 総計 9時間と減少し, 疲労設計上注意する必要性が増加する。

$C_{\mathrm{DIR}}$ を除いた同一条件下での $D_{10}\left[C_{\mathrm{DIR}}=-1\right] / D_{10}\left[C_{\mathrm{DIR}}=+1\right] の$ 值は $m=3$ のときで $1.7 \sim 8.7, m=5$ のときで $6.8 \sim 442$ を示し，平均成分 $C_{\text {om }}(j)$ が正となる $C_{\mathrm{DIR}}=-1$ の方が $C_{\mathrm{DIR}}=+1$ よりも大きな損傷率を示し 総じて平均応力成分が疲労損傷率に与える影響は大きい。このこと から, Fig. 1 中の L 型部材のように, 帳壁が外部に引っ張られる場 合と, 内部に押し込まれる場合の両方の応力状態に対して疲労を考 える必要のある部材については，今回検討対象としている応力時刻 歴特性では， $C_{\mathrm{DIR}}=-1$ について検討しておけば良いことになる。

\section{3 疲労損傷率算定用応力振幅の回数の検討}

本節では疲労損傷率検討用の応力振幅モデルの設定に向けて, 疲 労損傷率算定に用いる有効な応力振幅の回数を検討する。そのため, 今後は応力振幅数を表す $j(j=1$, namp $)$ ではなく, 近似に用いる振幅 数の $k\left(k=1, k_{\mathrm{all}}\right)$ で考える。先に検討したように, 壁面 $\mathrm{B}$ 上の代表 点 $\alpha, \beta, \gamma$ 疲労損傷率が大きな值となる風向は, その壁面が風向 に対して側面となる風向であり, 代表点の位置や無次元応力の統計 值（三風圧係数の統計值）の分布状況を考えると, 応力振幅の回数 の目安としてカルマン渦の発生回数を採用することが考えられる 20)。また, 代表点 $\gamma$ に発生する逆円錐状の渦の発生回数は, 角柱の ストロハル数に対応していることも報告されている ${ }^{21)}$ 。角柱のスト ロハル数 $S_{\mathrm{t}}$, 建物代表幅 $B(\mathrm{~m})$, 検討風速 $U_{\mathrm{H}}(\mathrm{m} / \mathrm{s})$ からカルマン渦の 発生周期 $T_{\text {voltex }}(\mathrm{sec})$ は次式で算定される。

$$
T_{\text {voltex }}=\frac{B}{S_{\mathrm{t}} \cdot U_{\mathrm{H}}} \quad(\mathrm{sec})
$$

以上より，全データ継続時間 $T_{\text {all }}(\mathrm{sec})$ および 10 分間 $(600 \mathrm{sec})$ 中に 考える有効な振幅回数 $k_{\text {all }}, k_{10}$ は次式となる。

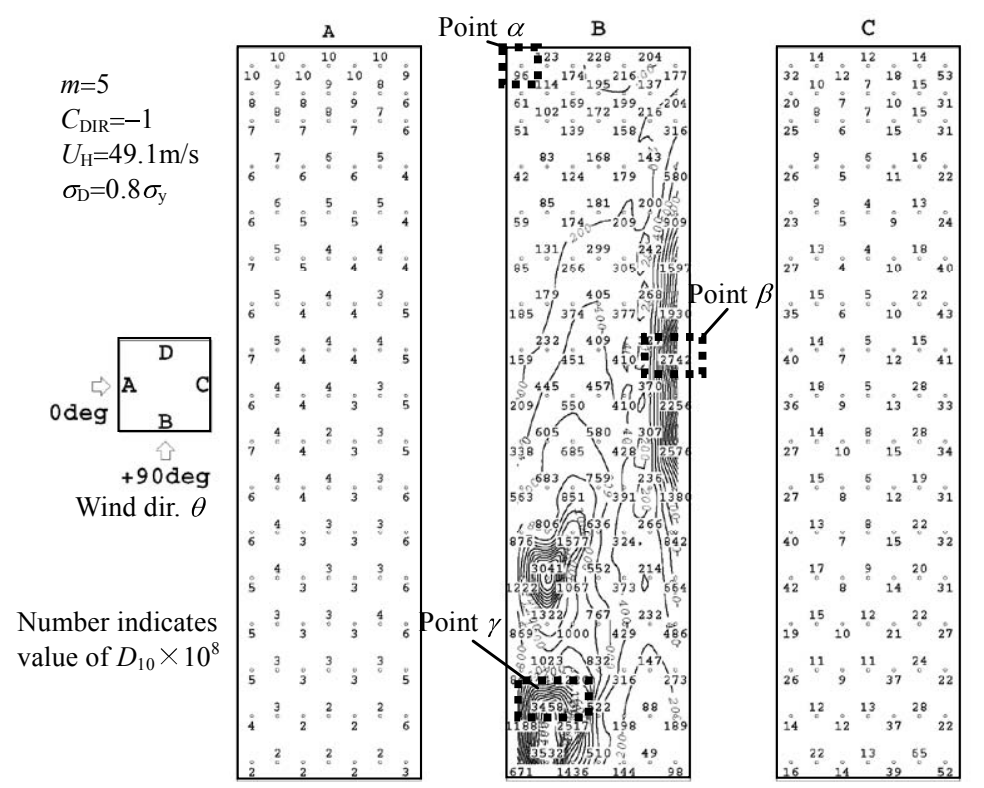

Fig.7 Distribution of $D_{10}$ on wall A,B,C, $\theta=0$ deg

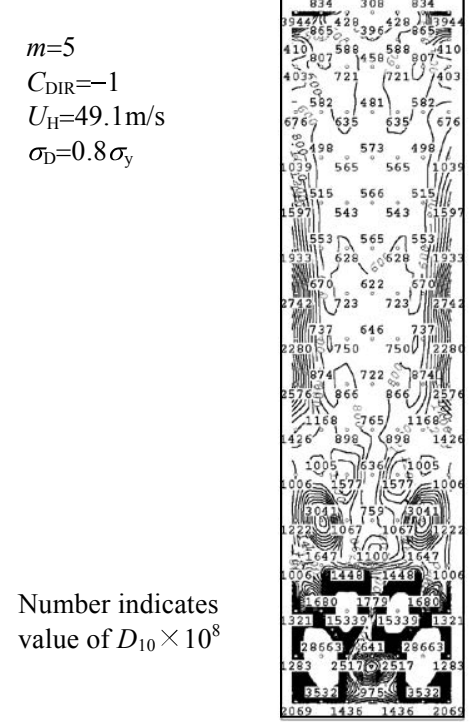

Fig. 8 Distribution of $D_{10}$ on wall (all wind dir.) 


$$
k_{\text {all }}=\frac{T_{\text {all }}}{T_{\text {voltex }}} \quad \text { (回) }, \quad k_{10}=\frac{600}{T_{\text {voltex }}} \quad \text { （回） }
$$

$B=50 \mathrm{~m}, S t=0.1, \quad U_{\mathrm{H}}=49.1 \mathrm{~m} / \mathrm{s}$ とした場合, $T_{\text {voltex }}=10.2 \mathrm{sec}, \quad k_{\text {all }}$ $=392$ 回, $k_{10}=58$ 回となる。

ここで, 設定した振幅数により各計測点の $D_{10}$ をどこまで評価可 能か調べるために, Fig. 12 に各計測点の $D_{10}$ 精算值の $95 \%$ の值とな るのに必要な振幅の数 $j(10$ 分間女たり $)$ を検討した例を示す。検討 条件は $U_{\mathrm{H}}=49.1 \mathrm{~m} / \mathrm{s}, \sigma \mathrm{D}=0.8 \sigma_{\mathrm{y}}, C_{\mathrm{DIR}}=-1, m=5$ である。図の横軸は 風圧測定点番号 (Fig. 3 参照) である。Fig. 12 (a) は全 72 風向につい て示し, Fig. 12 (b) は全風向中から計測点毎に $D_{10}$ が大きくなる 7 風 向を選び，それらに対する結果のみを示す。図の縦軸 $j$ は上で述べ た $k_{10}$ に対応する值である。Fig. 12 (a) 中の $j$ の最大值は 58 なので $k_{10}=58$ に対応寸る全データ回数 $k_{\mathrm{all}}=392$ 回を考慮すれば, それに基 づいて算定した $D_{10}$ は 95\%担保されることになる。ここで, Fig. 12 (a) は, 全風向の值を示しているので計測点が風上側壁面や風下側壁 面となる風向でも, 今回設定した $k_{10}$ の振幅数で $D_{10}$ の $95 \%$ は担保さ れていることになる。一方, Table 1 に $D_{10}$ の全風向中の最大值を $U_{\mathrm{H}}=49.1 \mathrm{~m} / \mathrm{s}$ の全ケースについて示すように, $D_{10}$ の值は $C_{\mathrm{DIR}}$ や $m$ の 影響を受ける。Fig. 12 の検討の $95 \%$ は仮に設定した值であるが, 逆 に今回設定した $k_{10}=58$ に対して $\sigma_{\mathrm{D}}=0.8 \sigma_{\mathrm{y}}$ の条件下で各ケースの条件 下で精算值の何パーセントまで担保可能かを検討した結果を Table 2 に示す。検討した風向は各計測点の $D_{10}$ が大きな値となる 7 風向 および全風向とし, 全計測点と代表点 $\alpha, \beta, \gamma$ それぞれについて值 を示すが, 式(23)中の $D_{10}$ 算定值の補正係数 dcorrec については Table 2 中の值のみを考慮した補正係数ではなく，後に示寸応力係数振幅
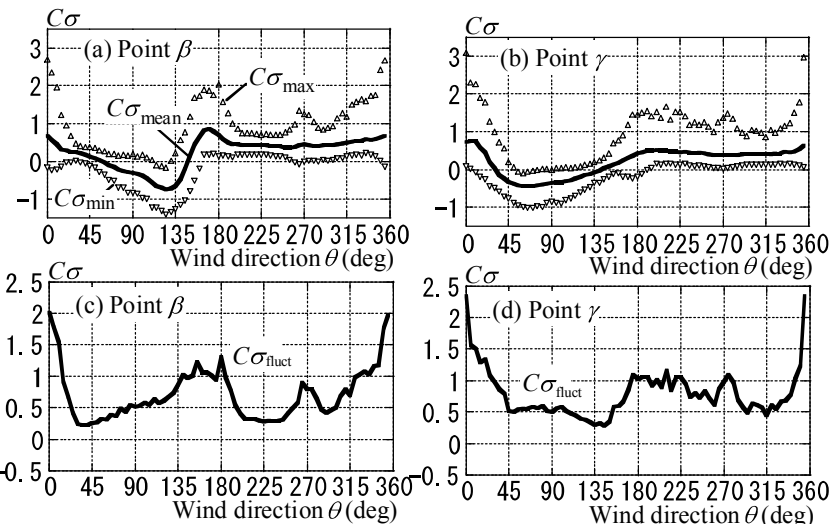
Fig. 9 Variation of $C_{\sigma}$ with $\theta$
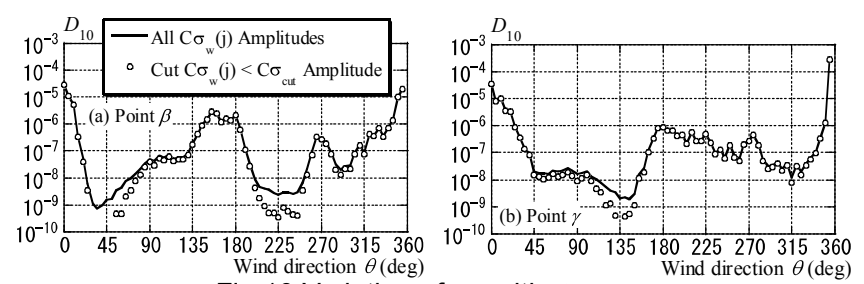

Fig. 10 Variation of $D_{10}$ with $\theta$
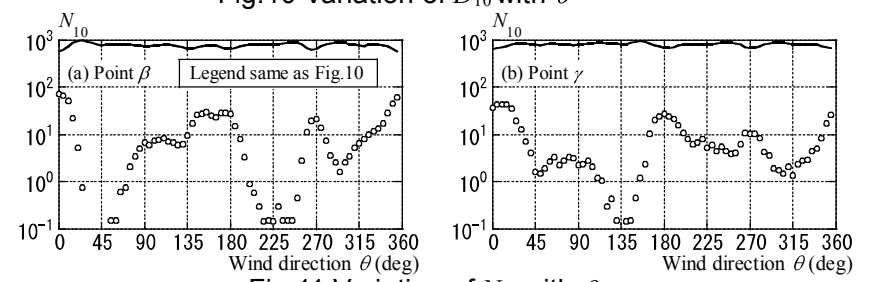

Fig. 11 Variation of $N_{10}$ with $\theta$
および平均値近似の誤差を含む Table 4 の值を採用する。

Table 1 Maximum $D_{10}$ values in all wind direction $\left(U_{\mathrm{H}}=49.1 \mathrm{~m} / \mathrm{s}\right)$

\begin{tabular}{|c|c|c|c|c|c|c|c|c|}
\hline \multirow[b]{2}{*}{ point } & \multirow[b]{2}{*}{$m$} & \multirow[b]{2}{*}{$C_{\mathrm{DIR}}$} & \multicolumn{2}{|c|}{$\sigma_{\mathrm{D}}=0.5 \sigma_{\mathrm{y}}$} & \multicolumn{2}{|c|}{$\sigma_{\mathrm{D}}=0.8 \sigma_{\mathrm{y}}$} & \multicolumn{2}{|c|}{$\sigma_{\mathrm{D}}=1.0 \sigma_{\mathrm{y}}$} \\
\hline & & & $D_{10}$ & $\begin{array}{r}\theta_{\text {ref }} \\
(\mathrm{deg})\end{array}$ & $D_{10}$ & $\begin{array}{r}\theta_{\text {ref }} \\
(\mathrm{deg})\end{array}$ & $D_{10}$ & $\begin{array}{r}\theta_{\text {ref }} \\
(\mathrm{deg})\end{array}$ \\
\hline \multirow{2}{*}{$\alpha$} & \multirow{6}{*}{5} & +1 & $2.45 \mathrm{E}-07$ & \multirow{2}{*}{015} & $1.88 \mathrm{E}-06$ & 035 & $5.59 \mathrm{E}-06$ & \begin{tabular}{|l|}
035 \\
\end{tabular} \\
\hline & & -1 & $1.66 \mathrm{E}-06$ & & $3.94 \mathrm{E}-05$ & 015 & $2.33 \mathrm{E}-04$ & 015 \\
\hline \multirow{2}{*}{$\beta$} & & +1 & $5.48 \mathrm{E}-07$ & \multirow{2}{*}{000} & $4.30 \mathrm{E}-06$ & \multirow{2}{*}{000} & $1.09 \mathrm{E}-05$ & \multirow{2}{*}{000} \\
\hline & & -1 & $1.72 \mathrm{E}-06$ & & $2.74 \mathrm{E}-05$ & & $1.14 \mathrm{E}-04$ & \\
\hline \multirow[b]{2}{*}{$\gamma$} & & +1 & $4.68 \mathrm{E}-07$ & \multirow{2}{*}{355} & $2.87 \mathrm{E}-06$ & \multirow{2}{*}{355} & $6.40 \mathrm{E}-06$ & \multirow{2}{*}{355} \\
\hline & & -1 & $7.13 \mathrm{E}-06$ & & $2.87 \mathrm{E}-04$ & & $2.83 \mathrm{E}-03$ & \\
\hline \multirow{2}{*}{$\alpha$} & \multirow{6}{*}{3} & +1 & $1.05 \mathrm{E}-06$ & 035 & $4.22 \mathrm{E}-06$ & 035 & $8.15 \mathrm{E}-06$ & 035 \\
\hline & & -1 & $1.81 \mathrm{E}-06$ & 015 & $1.08 \mathrm{E}-05$ & 015 & $2.82 \mathrm{E}-05$ & 015 \\
\hline \multirow{2}{*}{$\beta$} & & +1 & $1.93 \mathrm{E}-06$ & \multirow{2}{*}{000} & $6.76 \mathrm{E}-06$ & \multirow{2}{*}{00} & $1.20 \mathrm{E}-05$ & \multirow{2}{*}{00} \\
\hline & & -1 & $3.51 \mathrm{E}-06$ & & $1.78 \mathrm{E}-05$ & & $4.06 \mathrm{E}-05$ & \\
\hline \multirow[b]{2}{*}{ ( } & & +1 & $9.82 \mathrm{E}-07$ & 000 & $3.43 \mathrm{E}-06$ & 010 & $6.08 \mathrm{E}-06$ & 010 \\
\hline & & -1 & $2.08 \mathrm{E}-06$ & 355 & $153 \mathrm{E}-05$ & 355 & $526 \mathrm{~F}-05$ & 35 \\
\hline
\end{tabular}
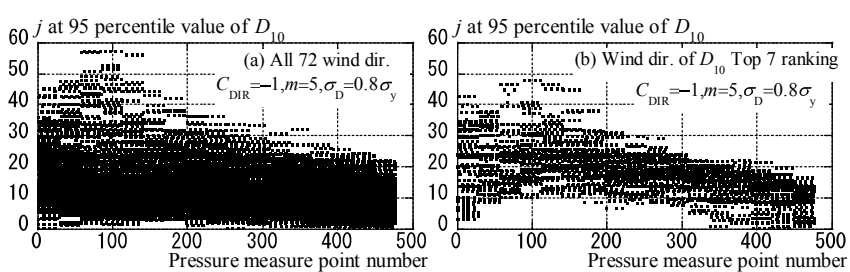

Fig.12 Effective $j$ value for 95 percentile value of $D_{10}$ at each point Table $2 D_{10}$ percentile values for $k_{\text {all }}=392$

\begin{tabular}{|c|c|c|c|c|c|}
\hline \multirow{2}{*}{$C_{\text {DIR }}$} & $m$ & \multicolumn{2}{|c|}{ All 476 point } & \multicolumn{2}{c|}{ Point $\alpha, \beta, \gamma$} \\
\cline { 3 - 6 } & $\begin{array}{c}\text { Upper } D_{10} \\
\text { rank of 7 } \\
\text { wind dir. }\end{array}$ & all wind dir. & $\begin{array}{c}\text { Upper } D_{10} \\
\text { rank of 7 } \\
\text { wind dir. }\end{array}$ & all wind dir. \\
\hline \hline \multirow{2}{*}{-1} & 5 & $95 \%$ & $95 \%$ & $95 \%$ & $95 \%$ \\
\cline { 2 - 6 } & 3 & $80 \%$ & $75 \%$ & $80 \%$ & $80 \%$ \\
\hline+1 & 5 & $95 \%$ & $95 \%$ & $95 \%$ & $95 \%$ \\
\cline { 2 - 6 } & 3 & $75 \%$ & $75 \%$ & $80 \%$ & $80 \%$ \\
\hline
\end{tabular}

\section{4. 疲労損傷率算定用の応力振幅と平均応力}

本節では無次元応力時刻歴 $C_{\sigma}(i)$ からレインフロー法により抽出 される疲労損傷率検討用の応力振幅 $C_{\sigma \mathrm{a}}(k)$ と平均応力 $C_{\sigma \mathrm{m}}(k)$ を風洞 実駼結果に基づいて近似する。検討対象は選定した 3 つ代表点の 疲労損傷率 $D_{10}$ が最大值となる風向 $\theta_{\mathrm{ref}}$ (Table 1 参照) とした。こ こでは，近似に用いる振幅数 $k$ は前節で検討した $k_{\mathrm{all}}=392$ とし，実 数型の変数 $\operatorname{prob}(k)$ を下式のように定める。

$$
\operatorname{prob}(k)=\frac{k}{k_{\text {all }}} \quad \text { for } k=1, k_{\text {all }}
$$

実験結果から求めた $C_{\sigma \mathrm{a}}(k)$ と $C_{\mathrm{om}}(k)$ を $k=1 \sim 392$ に対応する $\operatorname{prob}(k)$ を横軸として Fig. 13 に示すが， $C_{\text {бa }}(k)$ はその大きさでソート した值であり，そのソート順に対応した $C_{o \mathrm{~m}}(k)$ はばらつきが大きい。

\section{(a) 応力係数振幅の近似}
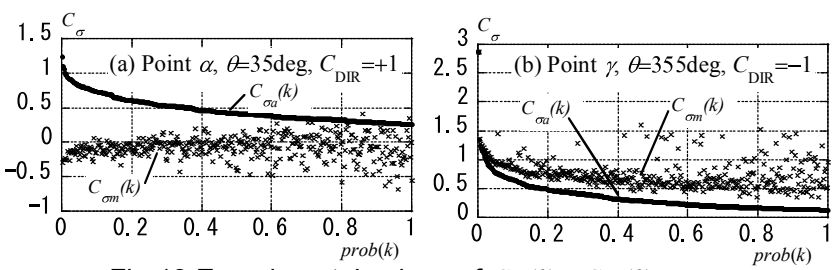

Fig.13 Experimental values of $C_{\sigma_{\mathrm{a}}}(k), C_{\mathrm{Om}}(k)$ 
Fig. 13 では $C_{\text {бa }}(k)$ は prob $(k)$ に対して漸減し, 滑らかな曲線となっ ている。 $C_{\sigma \mathrm{a}}(k)$ の近似については, 試行錯誤の結果, 下式のように $C_{\sigma a}(k) / C_{\text {ofluct }}$ の值を係数 $f_{\mathrm{a}}, f_{\mathrm{b}}$ を用いた関数で近似することとした。

$$
\frac{C_{\sigma_{\mathrm{a}}}(k)}{C_{\sigma_{\text {fluct }}}}=f_{\mathrm{a}}+f_{\mathrm{b}} \log (\operatorname{prob}(k))
$$

実験結果と近似式による算定結果をFig. 14 に示す。近似は，3つ の $\operatorname{prob}(k)$ の領域に分けて実施した。これは, Fig. 14 に示寸ように $C_{\sigma a}(k)$ の順位が高い $(k=1 \sim 4$ 程度) 振幅は, 応力時刻歴中のパルス 状のピークに対応するものが多く（特に Fig. 14(b) 中の代表点 $\gamma$ の $\theta_{\mathrm{ref}}=355^{\circ}$ における $k=1$ の振幅), 他の振幅とまとめて近似寸ること が困難であったためである。近似した係数 $f_{\mathrm{a}}, f_{\mathrm{b}}$ の值を Table 3 に 示し, 近似結果はFig. 14 中にシンボル $(\times,+)$ で示す。

3 つの領域境界で近似值が不連続となる部分がみられるものの, 近似值は概社実験結果を表現している。ただし，代表点 $\gamma, \theta_{\mathrm{ref}}=355^{\circ}$ では $k=1$ の大きな振幅を近似するために $k=2,3$ の振幅は実験值より 大きな值となっている。また, $C_{\sigma a}(k)$ が小さくなる $\operatorname{prob}(k)>0.2$ の領 域については, $0.01<\operatorname{prob}(k) \leqq 0.2$ における $f_{\mathrm{a}}, f_{\mathrm{b}}$ の值を用いると近似 值が実験值より大きくなり安全側の評価となるので, より簡便な近 似式とすることも可能である。なお，近似で考慮する $k_{\text {all }}$ の值によっ ては $\operatorname{prob}(k)<0.01$ となる $k$ が存在しないこともあるため, 近似に用 いる $k_{\text {all }}$ の值が今回の実験值で設定した $k_{\text {all }}=392$ 以上となるように実 大時間 $T_{\text {all }}(\mathrm{sec})$ を設定する (本検討では $U_{\mathrm{H}}=U_{\mathrm{HD}}$ の場合, $T_{\text {all }}$ は 67 分 程度に対応した值)。

\section{(b) 応力係数振幅平均值の近似}

既往の研究では, 疲労算定用の応力振幅と応力平均はそれぞれ独 立した值として取り扱かわれ, 文献 1)等では, 実験值に基づいた振 幅と平均值のマトリックスにより疲労損傷率を算定している。本論 文の実験值の振幅と平均值のマトリックスも他論文と同様な分布性 状を示すが, 本論文では以下の検討に基づき疲労損傷率算定上有効 な振幅について, 平均值を振幅值と風圧統計值の関数として近似す ることとした。

Fig. 13 を見ると， $C_{\text {om }}(k)$ はばらつきが大きいが，それぞれの絶対 值を考えると $C_{\sigma_{\mathrm{a}}}(k)$ と $C_{\mathrm{om}}(k)$ の相関は比較的高い。さらに, Fig. 5 (a) の応力波形 $\left(C_{\mathrm{DIR}}=-1\right)$ を見ると今回検討対象としている帳 壁に大きな負圧が作用するような波形は, 平均值より上側(引っ張り

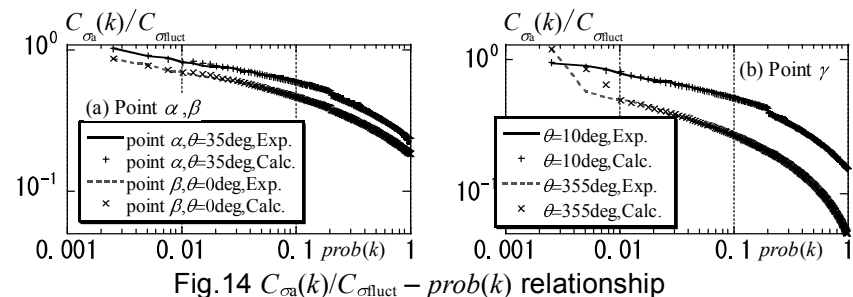

Table 3 Factors $f_{\mathrm{a}}$ and $f_{\mathrm{b}}$ for calculating the stress

\begin{tabular}{|c|c|c|c|c|c|c|}
\hline \multirow{2}{*}{ prob $(k)$} & \multirow{2}{*}{$\begin{array}{c}\text { factors } \\
\text { for } f(\mathrm{x})\end{array}$} & $\begin{array}{c}|c| \\
\theta_{\text {ref }}= \\
15(\mathrm{deg})\end{array}$ & $\begin{array}{c}\theta_{\text {ref }}= \\
35(\mathrm{deg})\end{array}$ & $\begin{array}{c}\theta_{\text {ref }}= \\
0(\mathrm{deg})\end{array}$ & $\begin{array}{c}\theta_{\text {ref }}= \\
10(\mathrm{deg})\end{array}$ & $\begin{array}{c}\theta_{\text {ref }}= \\
355(\mathrm{deg})\end{array}$ \\
\hline \multirow{2}{*}{$<0.01$} & $f_{\mathrm{a}}$ & $-6.95 \mathrm{E}-01$ & $1.68 \mathrm{E}-01$ & $9.36 \mathrm{E}-02$ & $2.95 \mathrm{E}-01$ & $-1.85 \mathrm{E}+00$ \\
\cline { 2 - 7 } & $f_{\mathrm{b}}$ & $-6.46 \mathrm{E}-01$ & $-3.32 \mathrm{E}-01$ & $-3.01 \mathrm{E}-01$ & $-2.58 \mathrm{E}-01$ & $-1.18 \mathrm{E}+00$ \\
\hline \multirow{2}{*}{$0.01 \sim 0.2$} & $f_{\mathrm{a}}$ & $4.71 \mathrm{E}-02$ & $3.32 \mathrm{E}-01$ & $2.06 \mathrm{E}-01$ & $2.42 \mathrm{E}-01$ & $4.32 \mathrm{E}-02$ \\
\cline { 2 - 7 } & $f_{\mathrm{b}}$ & $-2.74 \mathrm{E}-01$ & $-2.66 \mathrm{E}-01$ & $-2.61 \mathrm{E}-01$ & $-2.78 \mathrm{E}-01$ & $-2.29 \mathrm{E}-01$ \\
\hline \multirow{2}{*}{$0.2 \sim$} & $f_{\mathrm{a}}$ & $8.29 \mathrm{E}-02$ & $2.36 \mathrm{E}-01$ & $1.83 \mathrm{E}-01$ & $1.52 \mathrm{E}-01$ & $4.82 \mathrm{E}-02$ \\
\cline { 2 - 7 } & $f_{\mathrm{b}}$ & $-2.37 \mathrm{E}-01$ & $-3.58 \mathrm{E}-01$ & $-2.81 \mathrm{E}-01$ & $-3.58 \mathrm{E}-01$ & $-2.25 \mathrm{E}-01$ \\
\hline
\end{tabular}

側)のピーク值についてはピークファクタが大きく,下側のピークで はピークファクタはあまり大きくない。そこでFig. 15 に示すように $C_{\sigma a}(k)$ の值と応力係数の統計值を用いて下式のように变数 $x n(k)$ を導

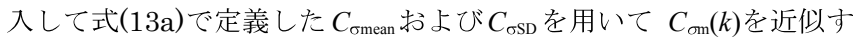
ることを試みた。

$\begin{array}{lll}C_{\sigma \mathrm{m}}(k)=-C_{\sigma \mathrm{a}}(k)+C_{\sigma \text { mean }}+x n(k) \times C_{\sigma \mathrm{SD}} & \left(\text { for } C_{\text {бmean }}<0\right) \\ C_{\sigma \mathrm{m}}(k)=+C_{\sigma \mathrm{a}}(k)+C_{\sigma \text { mean }}-x n(k) \times C_{\sigma \mathrm{SD}} & \left(\text { for } C_{\sigma \mathrm{mean}} \geqq 0\right)\end{array}$ ここでは $x n(k)$ を近似するための変数として $C_{\sigma a}(k)$ のピークファク タ $C_{g}(k)$ を用いる。

$$
C_{g}(k)=\frac{C_{\sigma_{\mathrm{a}}}(k)}{C_{\sigma_{\mathrm{SD}}}}
$$

Fig. 16 に $C_{\sigma \mathrm{a}}(k)$ と $C_{\sigma \mathrm{n}}(k)$ の実験值から逆算した $x n(k)$ と $C_{g}(k)$ の関係 を示す。データのばらつきは大きいが， $C_{g}(k)$ が大きいピークが損傷 率全体に占める割合が大きいので，検討対象とした 6 つの波形すべ てに対して $x n(k)$ の近似式として下式に示寸 2 折線を採用した。

$$
\begin{array}{ll}
x n(k)=0.34 \times C_{\mathrm{g}}(k)+0.9 & \left(\text { for } C_{\mathrm{g}}(k)<5\right) \\
x n(k)=0.08 \times\left(C_{\mathrm{g}}(k)-5\right)+2.6 & \left(\text { for } C_{\mathrm{g}}(k) \geqq 5\right)
\end{array}
$$

Fig. 17 に近似式で求めた $C_{\sigma a}(k)$ と $C_{\sigma \mathrm{m}}(k)$ (Fig. 13 に対応) を示す。 Table 4 に近似式で算定した $D_{10}$ を $U_{\mathrm{H}}=49.1 \mathrm{~m} / \mathrm{s}, \sigma \mathrm{D}=0.8 \sigma_{\mathrm{y}}$ について 示すが, $C_{\sigma \mathrm{a}}(k)$ と $C_{\text {on }}(k)$ の実験值から算定した $D_{10}$ と近似值から算定 した $D_{10}$ を比較すると, 代表点 $\alpha$ で最大 $15 \%, \beta$ で最大 $5 \%$, 代表点 $\gamma$ で最大 $40 \%$ の誤差が発生している。これは，代表点 Fig. 17 において振幅が大きい範囲において近似式と実験值の差が 大きいことが影響していると考えられる。この算定した誤差を式 (23)中の補正係数 dcorrec をとして採用し, 表中に示寸。この補正係 数は 3.3 節で検討した $k_{\text {all }}$ に起因する誤差も含んだ值である。 $m=3$ の補正係数で Table 4 に与えられないものは Table 2 の代表点の $k_{\text {all }}$ に関する值を参照して Table 4 の 1.2 倍 $(=0.95 / 0.8)$ の值を採用する。 (c) 式 (23) に使う $C_{\text {oa }}\left(\theta_{\mathrm{ref}}, k\right), C_{\text {or }}\left(\theta_{\mathrm{ref}}, k\right)$ について

式(23)に使用する $C_{\sigma \mathrm{\sigma a}}\left(\theta_{\mathrm{ref}}, k\right)$ は 3.4 節(a)で $\theta_{\mathrm{ref}}$ について算定した式 (28)の $C_{\sigma \mathrm{a}}(k)$ を, $C_{\text {or }}\left(\theta_{\mathrm{ref}}, k\right)$ は 3.4 節(b)で $\theta_{\mathrm{ref}}$ について算定した式 (29) の $C_{\sigma \mathrm{m}}(k)$ の值を用いる。

\section{5 疲労損傷率の風速による変化}

疲労損傷率の風速による変化については, 疲労曲線の傾きを示寸 定数 $m$ を用いて $D_{10}$ が風速の $2 m+1$ 乗に比例することが報告されて いる ${ }^{6)} 「 2 m+1 」 の う ち の 「 2 m 」 は$ 応力に対する倍率で, 「+1」は風

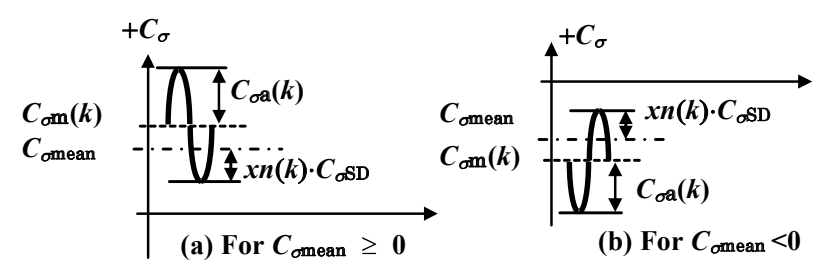

Fig.15 $x n(k)$ for $C_{\text {om }}(k)$ approximation

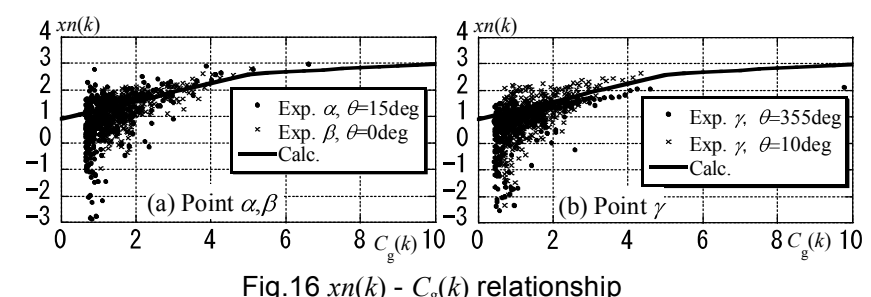

Fig.16 $x n(k)-C_{\mathrm{g}}(k)$ relationship 

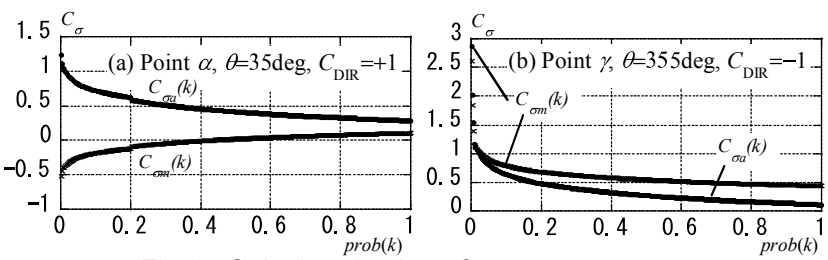

Fig. 17 Calculated value of $C_{\sigma \mathrm{a}}(k), C_{\text {om }}(k)$

Table 4 Comparison of calculated $D_{10}$ value with the experimental value and correction factor

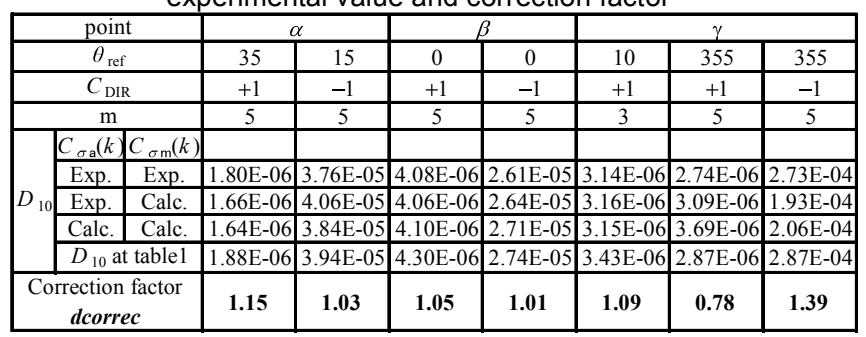

速に対応する時間軸(回数)に対する倍率である。本検討においても 応力振幅の平均成分の影響を無視して応力振幅 $C_{\sigma a}(k)$ から直接算定 した $D_{10}$ の風速による変化は風速の $2 m+1$ 乗に比例することを確認 した。本検討では $D_{10}$ の算定で応力の平均成分を修正 Goodman 法 により考慮しているため，平均成分の影響を考慮した場合には Fig. 18 に示寸ように算定した $D_{10}$ の風速による変化は $2 m+1$ 乗の線 からずれが生じる。

ここでは, 上記の $2 m+1$ に対応するべき指数として变数 $L$ を導入 ᄂ, 風向 $\theta_{\mathrm{ref}}$ で設計風速 $U_{\mathrm{HD}}$ 時の疲労損傷率を $d_{10}\left(U_{\mathrm{HD}}, \theta_{\mathrm{ref}}\right)$, 検討風 速 $U_{\mathrm{H}}$ 時の疲労損傷率を $d_{10}\left(U_{\mathrm{H}}, \theta_{\mathrm{ref}}\right)$ として風速 $U_{\mathrm{H}}$ による修正係数 $\operatorname{ufact}\left(U_{\mathrm{H}}\right)$ を下式で近似することとした。

$$
\operatorname{ufact}\left(U_{\mathrm{H}}\right)=\frac{d_{10}\left(U_{\mathrm{H}}, \theta_{\mathrm{ref}}\right)}{d_{10}\left(U_{\mathrm{HD}}, \theta_{\mathrm{ref}}\right)}=\left(\frac{U_{\mathrm{H}}}{U_{\mathrm{H}_{\mathrm{D}}}}\right)^{L}
$$

実験風向中最大の $D_{10}$ を与える $\theta_{\mathrm{ref}}$ について, $U_{\mathrm{HD}}=49.1 \mathrm{~m} / \mathrm{s}$ とし, $U_{\mathrm{H}}=1 \sim 60 \mathrm{~m} / \mathrm{s}$ の範囲を $0.5 \mathrm{~m} / \mathrm{s}$ ピッチで実験結果から直接算定した ufact $\left(U_{\mathrm{H}}\right)$ を近似する。Fig. 18 に示すように $L$ の值が $2 m+1$ と異なっ ており, その傾きが高風速側と低風速側で異なるので, $U_{\mathrm{HD}}$ を境と して $U_{\mathrm{H}}=15 \sim 49.1 \mathrm{~m} / \mathrm{s}$ の範囲で近似した值を $L_{\mathrm{L}}, U_{\mathrm{H}}=49.1 \sim 60 \mathrm{~m} / \mathrm{s}$ の範囲で近似した值を $L_{\mathrm{H}}$ として Table 5 に示す。Fig. 18 に近似結 果(図中の+)も示す。 $C_{\mathrm{DIR}}=-1$ のケースでは $L$ の值は $2 m+1$ より大き くなり $\left(L_{\mathrm{L}}\right.$ or $\left.L_{\mathrm{H}}\right) /(2 m+1)=1.11 \sim 2.02, L_{\mathrm{H}} / L_{\mathrm{L}}=1.11 \sim 1.57, C_{\mathrm{DIR}}=+1$ のケースでは $L$ の值は $2 m+1$ より小さくなり $\left(L_{\mathrm{L}}\right.$ or $\left.L_{\mathrm{H}}\right) /(2 m+1)=0.75$ $\sim 1.00, L_{\mathrm{H}} / L_{\mathrm{L}}=0.87 \sim 1.01$ となっていた。

\section{6 疲労損傷率の風向による変化}

Fig. 10 に示寸実験值の疲労損傷率 $D_{10}$ の風向による変化は, Fig. $9(\mathrm{c}), \quad(\mathrm{d})$ に示寸 $C_{\text {ofluct }}$ の風向による変化と非常に高い相関がみ られた。ここでは, 風向 $\theta$ における $d_{10}\left(U_{\mathrm{HD}}, \theta\right)$ と $C_{\text {ofluct }}(\theta)$ と実験にお いて, $d_{10}\left(U_{\mathrm{HD}}, \theta_{\mathrm{ref}}\right)$ が全風向中の最大值となるリファレンス風向 $\theta_{\mathrm{ref}}$ 時の $C_{\text {olluct }}\left(\theta_{\mathrm{ref}}\right)$ を用い, $d_{10}\left(U_{\mathrm{HD}}, \theta\right)$ を心゙き指数 $n$ を用いた下式で近似 することとした。

$$
d_{10}\left(U_{\mathrm{HD}}, \theta\right)=d_{10}\left(U_{\mathrm{HD}}, \theta_{\text {ref }}\right) \times\left(\frac{C_{\text {ofluct }}(\theta)}{C_{\text {ofluct }}\left(\theta_{\text {ref }}\right)}\right)^{n}
$$
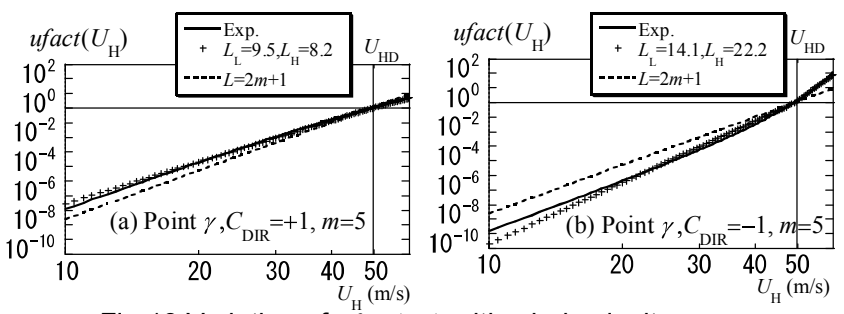

Fig. 18 Variation of $u f a c t\left(U_{\mathrm{H}}\right)$ with wind velocity $U_{\mathrm{H}}$

\begin{tabular}{|c|c|c|c|c|c|c|c|c|c|c|c|c|}
\hline \multirow{3}{*}{ point } & \multicolumn{6}{|c|}{$C_{\text {DIR }}=-1$} & \multicolumn{6}{|c|}{$C_{\mathrm{DIR}}=+1$} \\
\hline & \multicolumn{3}{|c|}{$m=5$} & \multicolumn{3}{|c|}{$m=3$} & \multicolumn{3}{|c|}{$m=5$} & \multicolumn{3}{|c|}{$m=3$} \\
\hline & $L_{\mathrm{L}}$ & $L_{\mathrm{H}}$ & $\theta_{\text {ref }}$ & $L_{\mathrm{L}}$ & $L_{\mathrm{H}}$ & $\theta_{\text {ref }}$ & $L_{\mathrm{L}}$ & $L_{\mathrm{H}}$ & $\theta_{\text {ref }}$ & $L_{\mathrm{L}}$ & $L_{\mathrm{H}}$ & $\theta_{\text {ref }}$ \\
\hline$\alpha$ & 12.9 & 17.2 & 15 & 7.9 & $\begin{array}{l}9.8 \\
\end{array}$ & 15 & 10.9 & 10.8 & 35 & \begin{tabular}{|l|}
7.0 \\
\end{tabular} & \begin{tabular}{|l|}
7.0 \\
\end{tabular} & 35 \\
\hline $\bar{\beta}$ & 12.0 & 13.8 & $\overline{0}$ & 7.5 & 8.4 & $\overline{0}$ & 10.2 & 9.3 & $\overline{0}$ & 6.6 & 6.2 & 0 \\
\hline$\gamma$ & 14.1 & 22.2 & 355 & 8.3 & 12.5 & 355 & 9.5 & 8.2 & 355 & \begin{tabular}{|l|}
6.6 \\
\end{tabular} & \begin{tabular}{|l|}
6.2 \\
\end{tabular} & 10 \\
\hline
\end{tabular}
Table 5 Approximated values of $L_{\mathrm{L}}$ and $L_{\mathrm{H}}$

式(33)中のべき指数 $n$ の值は, $m$ に近い值となることが予想され たが, 代表点の $C_{\text {ofluct }}(\theta)$ の範囲が $0.3 \sim 2.4$ 程度なのに対して, $d_{10}\left(U_{\mathrm{HD}}, \theta\right)$ の範囲はオーダーが大きく異なる点もあり, $n$ については $d_{10}\left(U_{\mathrm{HD}}, \theta\right)$ が実験值に近くなるように $n=2.4 \sim 7$ の值を設定した(Table 6)。また, $d_{10}\left(U_{\mathrm{HD}}, \theta_{\mathrm{ref}}\right)$ の発生風向 $\theta_{\mathrm{ref}}$ と $C_{\text {ofluct }}(\theta)$ の最大值の発生風 向は必ずしも一致しないため修正係数 $t f a c t(\theta)$ の值は 1.0 を上限值と した下式を採用した。

$$
\operatorname{tfact}(\theta)=\min \left(1.0,\left(\frac{C_{\text {ofluct }}(\theta)}{C_{\text {ofluct }}\left(\theta_{\text {ref }}\right)}\right)^{n}\right)
$$

Fig. 19 に, 代表点 $\alpha$ におけ $\operatorname{tfact}(\theta)$ の実験値とその近似式の風向 による変化の例を示す。近似結果は比較的良好に実験結果を表現す るが, $C_{\mathrm{DIR}}=-1$ のケースよりも $C_{\mathrm{DIR}}=+1$ のケースの方が近似精度は悪 くなる傾向があった。これは, $C_{\mathrm{DIR}}=+1$ では振幅 $C_{\sigma \mathrm{w}}(j)$ が小さくなり, そのべき乗を総和した損傷率に占める下位ピークの割合が増加して 統計最大值 $C_{\text {ofluct }}(\theta)$ との誤差が増えるためと考えられる。
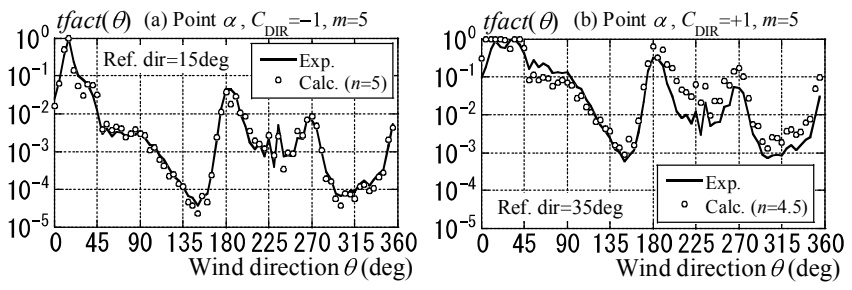

Fig. 19 Variation of $\operatorname{tfact}(\theta)$ with wind direction

Table 6 Approximated values of $n$ for the reference $\theta_{\text {ref }}$

\begin{tabular}{|c|c|c|c|c|c|c|c|c|}
\hline \multirow{3}{*}{ point } & \multicolumn{3}{|c|}{$C_{\text {DIR }}=-1$} & \multicolumn{4}{c|}{$C_{\text {DIR }}=+1$} \\
\cline { 2 - 9 } & \multicolumn{2}{|c|}{$m=5$} & \multicolumn{2}{c|}{$m=3$} & \multicolumn{2}{c|}{$m=5$} & \multicolumn{2}{c|}{$m=3$} \\
\cline { 2 - 9 } & $n$ & $\theta_{\text {ref }}$ & $n$ & $\theta_{\text {ref }}$ & $n$ & $\theta_{\text {ref }}$ & $n$ & $\theta_{\text {ref }}$ \\
\hline$\alpha$ & 5.0 & 15 & 2.4 & 15 & 4.5 & 35 & 3.0 & 35 \\
\hline$\beta$ & 5.0 & 0 & 3.0 & 0 & 4.0 & 0 & 2.4 & 0 \\
\hline$\gamma$ & 7.0 & 355 & 3.0 & 355 & 5.0 & 355 & 3.0 & 10 \\
\hline
\end{tabular}

\section{4. まとめ}

変動風圧実験で得られた変動外圧時刻歴を用いて, 帳壁緊結部の ボルトにおける実大 10 分間相当の疲労損傷率 $D_{10}$ を算定しその特徵 を検討した。疲労損傷率の算定方法として風外力と部材応力の方向 を定義する変数 $C_{\mathrm{DIR}}$ を導入し, さらに, 無次元化した応力係数 $C_{\sigma}$ を用いて平均成分を考慮した疲労損傷率 $D_{10}$ を算定する方法を示し 
た。

塔状比 4 の角柱状建物の帳壁部位から疲労損傷率 $D_{10}$ が大きくな る代表点 3 点を選定し, 応力係数時刻歴から抽出される応力振幅お よびその平均值の特徴を近似する式を提案することも含め, 詳細に 検討した。

設計風速における疲労損傷率 $D_{10}$ は, 今回検討したケース中の最 大值で $2.83 \times 10^{-3}$ となり，3.2 節で検討したように, 疲労設計上疲労 損傷が発生する確率は低いことが分かった。これは, $D_{10}$ が $\sigma_{\mathrm{f}}$ 值の影 響を大きく受けることと, L1 風速時に実大 10 分間の応力振幅の繰 り返し数は 1,000 回弱となるが， $D_{10}$ の值に直接影響する大きな振 幅の数はカルマン渦の発生回数 60 回程度と数が少ないことが一因 である。一方, 時刻歴で損傷率を評価すると, ピーク風圧係数統計 值ではアンサンブル平均に埋もれてしまうパルス状の波形に対応す る小数の大きな応力振幅が $D_{10}$ に多大な影響を与えることが判明し た。損傷率を評価するための実験データの継続時間と統計值の取り 扱いについては，今後さらなる検討が必要である。

外力の平均成分が $D_{10}$ に与える影響は大きく, 同一波形の正負を 逆転させた場合, $D_{10}$ 值に 400 倍以上の差が見られるケースもあり， $D_{10}$ の風速による変化にも平均成分は大きく影響していた。 $D_{10}$ の風 向による変化は $C_{\sigma}$ 統計值から求めた変動成分のべき指数を用いた 係数 $\operatorname{tfact}(\theta)$ で比較的良好に近似できたが，ここにも外力の平均值の 影響が見られ，波形毎に異なった心゙き指数となっていた。

本論文は非常に多くの簡略化と仮定条件に基づいているが， 2.7 節に概要を示した実験結果の近似式を用いて算定した風向・風速に 対応した $d_{10}\left(U_{\mathrm{HD}}, \theta_{\mathrm{ref}}\right)$ を用いることにより, 実験による時刻歴を直 接用いた場合に近い精度で疲労損傷率を検討可能と思われる。ただ し，検討に用いる設計風速がそれぞれの近似值に与える影響や，別 実験の統計值の適用など，汎用的な設計手法として展開するために はさらなる検討が必要である。

最後に, 外装材またはその応力伝達経路の部材の疲労設計を考え る場合，使用される材質が鉄鋼以外のアルミニウム合金等の場合も 多く，その断面形状も多岐にわたるために，各種材料や部材形状に 対する基本疲労強度についてもさらなる検討が必要である。

\section{参考文献}

1) E. D. Jancauskas, M. Mahendran, G. R. Waker : Computer simulation of the fatigue behavior of roof cladding during the passage of a tropical cyclone, J. of Wind Eng., Vo1.51, pp. 215 227, 1994

2) A.Baskaran, Y.Chen : Windload cycle development for evaluating mechanica11y attached single-ply roofs, J. of Wind Eng., Vol. 77\&78, pp. 83 96, 1998

3) K. Surech Kumar, T. Statopoulos: Fatigue analysis of roof cladding undersimulated wind loading, J. of Wind Eng., Vol. $77 \& 78$, pp. 171 183, 1998

4) 古市圭, 植松康, 中村修治, 世良昌也 : 機械固定式防水システムの動風圧 評価法に関する研究，第 19 回風工学シンポジウム, pp. 471〜476, 2010. 12

5) 高森浩治, 西村宏昭, 谷口徹郎, 谷池義人: 外装材の疲労評価のための変 動風圧時系列の作成, 第 21 回風工学シンポジウム, pp. 417〜 422, 2010.12

6）松井正宏, 田村幸雄: 外装材, 構造骨組に対する風による累積疲労損傷度 の評価式, 日本建築学会大会学術講演梗概集 構造 I , pp. 213 214, 2013.8

7）多賀直恒, 岡田恒, 河瑛徹 : 風力によるアルミサッシ空枠接合部の累積疲 労損傷, 日本風工学会誌, No. 50, pp. $3 \sim 18,1992.2$
8）河井宏充, 藤田正則 : 外装材等の耐風疲労設計, 日本建築学会大会学術講 演梗概集 B-1 構造 I , pp. 137〜138，2005.9

9）松井正宏，佐藤俊則：外装材に対する風による累積疲労損傷度，日本建築 学会大会学術講演梗概集 構造 I, pp. 247 248, 2014.9

10）建築物荷重指針 · 同解説 2004，（社）日本建築学会, 丸善株式会社, 2004.9 11）寺崎浩, 中村良平：風上側の建物が高層建物の外装材用風荷重に与える 影響，第 21 回風工学シンポジウム論文集，pp. 299〜 304，2010. 12

12）寺崎浩, 浅見豊, 東山博人 : 固有直交関数展開による変動風圧の評価, 大成建設技術研究所報，第 29 号, pp. 155-158, 1996

13) T.V.Lawson : Wind effects on building Vol.1,2, Applied Science Publishers LTD, 1980

14）JIS B1051:2000（I898-1：1999），炭素鋼及び合金鋼製締結用部品の機械的 性質 第 1 部：ボルト，ねじ及び植込みボルト，(財) 日本規格協会，2000 15）鋼構造物の疲労設計指針・同解説, （社）日本鋼構造協会, 技法堂出版, 2012.6

16）山本晃：ねじ締結の原理と設計，養賢堂，1996.1

17）奥田泰雄，谷池義人：3 次元角柱まわりの流れと圧力場についてその 3 角柱側面上の渦構造, 日本建築学会大会学術講演梗概集 B 構造 I, pp. 103 $\sim 104, \quad 1990.9$

18）奥田泰雄，桂順治，川村純夫 : 自然風中に置かれた 3 次元角柱に加わる 風圧力の計測 野外計測用多チャネルデータ計測システム, 日本建築学会大 会学術講演梗概集 B 構造 I , pp. 229～230， 1994.7

19）寺崎浩, 植松康 : 風外力を受ける高層建物の外装材疲労損傷評価に関寸 る研究, 第 22 回風工学シンポジウム, pp. 311-316, 2012.12

20）寺崎浩，植松康：風外力を受ける高層建物の外装材疲労損傷評価に関す る研究その 2 , 日本建築学会大会学術講演梗概集 構造 I, pp. 211-212, 2013. 8

21）日比一喜, 田村幸雄, 上田宏, 菊池浩利：高層建物に作用寸るピーク風 圧力の特性 その 1 側面に発生するパルス状のピーク波形, 日本風工学会誌 第 71 号 年次発表研究会梗概集, pp. 117-118, 1997.4

\section{付録}

本論文の実験結果に基づく近似式を用いて疲労損傷率を算定するためには， 代表点 $\alpha, \beta, \gamma$ における風力係数 $C_{\mathrm{f}}$ の統計值が必要となる。Table A に実験に おける 72 風向の統計值を 16 方位に集約した值を示す。集約にあたっては実 験風向 $\theta=0^{\circ}$ を方位 $\mathrm{N}$ とし, 一方位に含まれる複数の実験風向より $C_{\mathrm{DIR}}=-1$ の条件で $D_{10}$ 值が大きくなる $\theta$ を選定した(Fig. A 参照)。参考として表中には 各方位に採用された実験風向 $\theta$ を示し，さらに，全風向中で最大の $D_{10}$ を算定 するときに選定する方位 $\left(\theta_{\mathrm{ref}}\right)$ を”ref for $C_{\mathrm{DIR}}$ として, $C_{\mathrm{DIR}}= \pm 1$ について示す。

Table A $C_{\mathrm{f}}$ Statistical values for fatigue calculation
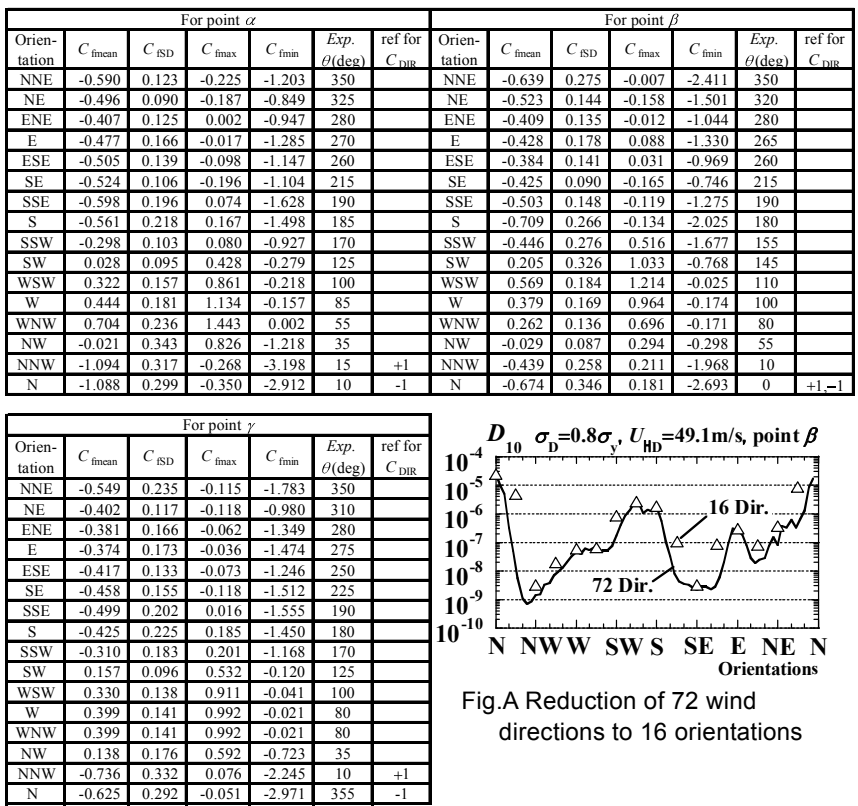

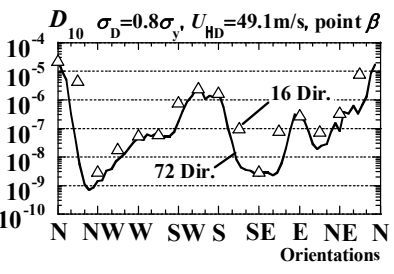

Fig.A Reduction of 72 wind directions to 16 orientations 


\title{
CHARACTERISTICS OF WIND FORCES ACTING ON EXTERNAL WALL BINDERS OF HIGH-RISE BUILDINGS FROM THE VIEWPOINT OF FATIGUE DAMAGE
}

\author{
Hiroshi TERAZAKI* and Yasushi UEMATSU**
}

\footnotetext{
* Senior Research Engineer, Disaster Prevision Research Section, Building Engineering Research Institute, Tech. Center, Taisei Corp., M. Eng. ** Prof., Dept. of Architecture and Building Science, Tohoku Univ., Dr. Eng.
}

The cladding and components of high-rise buildings are always exposed to dynamic wind forces. The wind forces are characterized by a long duration compared with seismic forces. For example, during a strong typhoon, strong wind lasts for a couple of hours. The structural frames of high-rise buildings are usually designed so that the stresses involved in the structural members are almost in the elastic range for the design wind speed with a return period of 500 years. On the other hand, in many cases, the cladding and components are designed based on the short-term allowable stress for the design wind speed with a return period of 50 years. Therefore, they may be damaged by fatigue during the building's lifetime.

The present paper discusses the characteristics of wind forces acting on the external wall binders of a high-rise building based on the results of a wind tunnel experiment from the viewpoint of fatigue damage.

In chapter 2, assumed conditions and the study methods are introduced.

High-rise building used as a consideration is $200 \mathrm{~m}$ height with its shape ratio of $B: D: H=1: 1: 4$. Special attention is paid to the binders connecting the external curtain walls and the structural frames(section 2.2). In examining fatigue damage ratio, the influence of mean component of wind force is taken into consideration(section 2.3). The fatigue property values for fatigue evaluation is based on Japanese recommendations(section2.5). A wind force direction conversion factor $C_{\mathrm{DIR}}$ is introduced to the fatigue evaluation, which represents the sign of wind force and stress.

Furthermore, the modified Goodman method is employed to consider the effect of mean components of stress amplitudes on the fatigue damage. And a method of fatigue damage evaluation is proposed based on the normalized stress(section 2. 6). In section 2.7, the outline of an approximation method for fatigue damage described.

In chapter 3 , the fatigue damage ratios and related values for fatigue damage calculation based on the experiment are discussed on the three representative points. And through the seeking approximation methods and factors for experimental results approximation, the property of wind force discussed on the viewpoint of fatigue damage, especially effects of mean component of wind force.

Using the time history of wind pressure coefficients derived from the wind tunnel test, the fatigue damage ratio is evaluated under some assumed conditions. And the points $\alpha, \beta, \gamma$ with large fatigue damage ratio are selected as three representative points(section 3.1). The effects of mean component of normalized stress on fatigue damage ratio are discussed, using a factor $C_{\mathrm{DIR}}$ representing the relation between the sign of wind load and that of member stress (section 3.2). The effective number of normalized stress amplitude is introduced to evaluate the fatigue damage ratio approximately(section 3.3). An approximation method is proposed to evaluate the amplitudes and means of the normalized stress (section 3.4). The effect of wind speed on the fatigue damage ratio is discussed using the approximations of experimental results(section 3.5). The effect of wind direction on the fatigue damage ratio is discussed(section 3.6).

Some information obtained from the wind tunnel experiment used for evaluating the fatigue damage is provided in the appendix.

The method for evaluating fatigue damage proposed in the present paper uses many approximations and assumptions based on the result of a wind tunnel experiment. Using this method, we can easily evaluate the fatigue damage of external wall binders of high-rise building. The concept can be applied to the other cladding and components. 